\title{
The Vulnerability of Tourism Firms' Stocks to Terrorist Incidents
}

\section{Dlawar Mahdi Hadi}

\author{
Submitted to the \\ Institute of Graduate Studies and Research \\ in partial fulfillment of the requirements for the degree of
}

Doctor of Philosophy

in

Finance

Eastern Mediterranean University

May 2019

Gazimağusa, North Cyprus 
Approval of the Institute of Graduate Studies and Research

\section{Prof. Dr. Ali Hakan Ulusoy}

Acting Director

I certify that this thesis satisfies all the requirements as a thesis for the degree of Doctor of Philosophy in Finance.

Chair, Department of Banking and Finance

We certify that we have read this thesis and that in our opinion it is fully adequate in scope and quality as a thesis for the degree of Doctor of Philosophy in Finance.

Prof. Dr. Cahit Adaoğlu

Co-Supervisor
Prof. Dr. Salih Katırcıŏlu Supervisor

Examining Committee

1. Prof. Dr. Murat Donduran

2. Prof. Dr. Fazıl Gökgöz

3. Prof. Dr. Salih Katircioğlu

4. Prof. Dr. Nesrin Özataç

5. Asst. Prof. Dr. Setareh Katırcıoğlu 


\begin{abstract}
This thesis aims to examine the effect of terrorist incidents on the performance of tourism, travel, and leisure firms in the world's leading tourism countries namely China, France, Germany, Spain, Thailand, Turkey, United Kingdom, and the United States. This thesis, specifically, investigates the influences of terrorist incidents on the firm's stock returns and volatility using event study and Generalized Autoregressive Conditional Heteroscedasticity family models. The novelty of this research is that not only it focuses on the relationship between terrorism and tourism stock performance and volatility but also uses an event study to examine this relationship. The findings of this study reports the significant effects of the terrorist attacks on tourism firms' performance in France, Spain, Thailand, Turkey, the United Kingdom, and the United States. The significant effects of the terrorist attacks on tourism firms' stock volatility, however, were only obtained for France, Thailand, and the United States. These effects were particularly long-lasting in Turkey, Germany, Spain, Thailand, the United Kingdom, and the United States. The overall panel event study analysis as well as the event study for individual countries illustrated the considerable adverse effects of terrorist attacks on firms' performance in tourism, travel, and leisure industries. The findings of this study are consistent with the Efficient Market Hypothesis, while the results are expected to be of high importance for the financial managers, investors, and portfolio managers.
\end{abstract}

Keywords: Terrorist incidents, Top tourist destinations, Tourism firms, Stock returns, Volatility, Event study 


\section{ÖZ}

Bu tez terörizm olaylarının, turizm, seyahat ve başta Çin, Fransa, Almanya, İspanya, Birleşik Krallık,Tayland, Türkiye ve Birleşik Devletleri gibi dünyanın önde gelen turizm ülkelerindeki eğlence firmalarının performansı üzerindeki etkilerini incelemektedir. Bu tez özellikle, terörist olaylarının şirketin hisse senedi getirileri ve değişimleri üzerindeki etkilerini durum çalışmasıyla ve Genelleştirilmiş Otoregressive Koşullu Heterosidasyon eğitimi aile modelleriyle incelemektedir. $\mathrm{Bu}$ çalışmanın yenliği sadece turizm hisse performansı ve değişimini ile terörizm arasındaki ilişkiye odaklanması değil aynı zamanda bu ilişkiyi incelemek için bir durum çalışmasının incelenmesidir. Çalışmanın sonuçları Fransa, İspanya, Tayland, Türkiye, Birleşik Krallık ve Birleşik Devletleri'ndeki turizm şirketlerinin, terörizm saldırılarında önemli derecede etkilendiğini göstermiştir. Terörizm saldırılarının turizm şirketlerinin hisse senedi değişimi üstündeki belirgim etkileri sadece Fransa, Tayland ve Birleşik Devletler için tespit edilmiştir. Bu etkiler özellikle Türkiye, Almanya, İspanya, Tayland, Birleşik Krallık ve Birleşik Devletler için daha uzun ömürlüdür. Genel panel durum çalışması analizinin yanı sıra tek tek ülkeler için yapılan durum çalışması, terörist saldırıların, firmaların turizm, seyahat ve eğlence endüstrilerindeki performansı üzerindeki önemli olumsuz etkilerini olduğu tespit edilmiştir. Bu çalışmanın bulguları, Verimli Pazar Hipotezi ile tutarlıdır, ancak bu sonuçların finansal yöneticiler, yatırımcılar ve portföy yöneticileri için yüksek öneme sahip olması beklenmektedir.

Anahtar Kelimeler: Terörist olayları, Popüler turist yerleri, Turizm şirketleri, Değişim, Durum çalışması 
To Malik and Mamand 


\section{ACKNOWLEDGMENT}

I would like to express gratitude to Allah, the merciful and compassionate, for giving me good health, wisdom, wellbeing, knowledge, those were necessary to complete my education.

I also would like to thank my supervisor Prof. Dr. Salih Katırcıoğlu and to my cosupervisor Prof. Dr. Cahit Adaoğlu for their knowledge, valuable and helpful guidance and suggestions during the preparation of this thesis enabling me to finish this thesis. Indeed, I cannot thank you enough for helping me.

I would like to extend my sincere thanks to Prof. Dr. Gulcay Payaslioğlu for her assistance, in particular, in volatility section in my thesis.

I would like to dedicate my thesis to my parents. I wish they were healthy enough to appreciate this moment and celebrate with me.

Last but not least, I would like to express my earnest gratefulness to my wife (Avin) for her support, patience, and understanding throughout studying my $\mathrm{PhD}$. In fact, it could be unachievable without her. 


\section{TABLE OF CONTENTS}

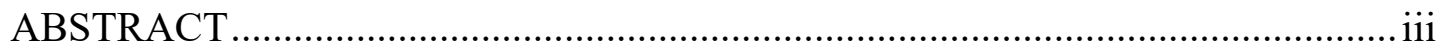

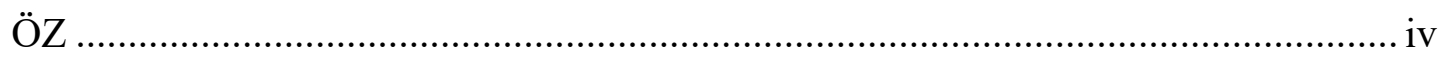

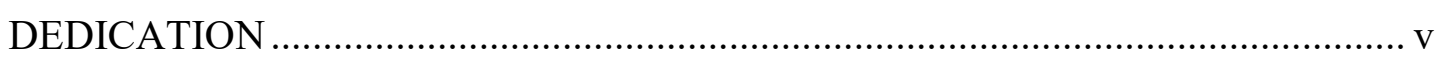

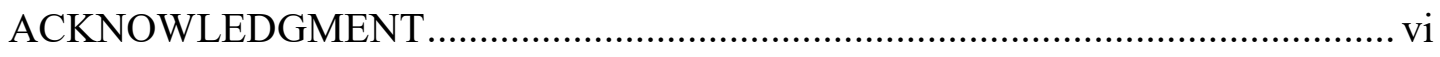

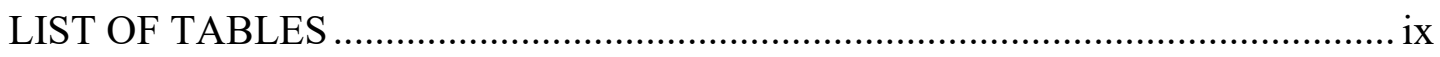

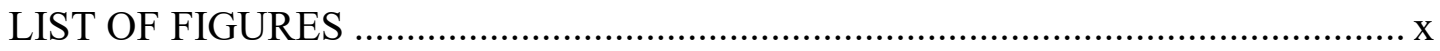

LIST OF ABBREVIATIONS .......................................................................

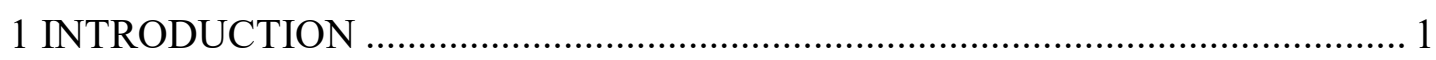

1.1 The Study's Background.............................................................. 1

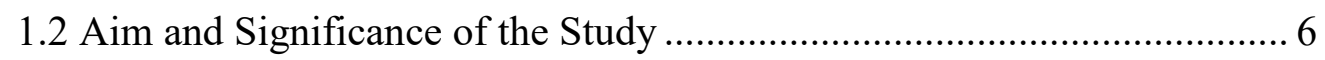

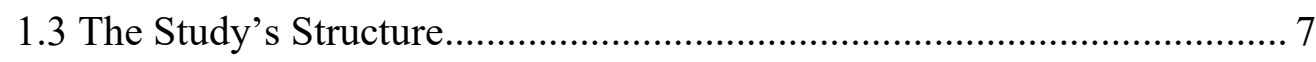

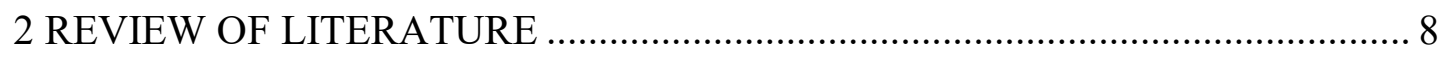

2.1 World's Top Tourist Destinations.................................................... 8

2.2 The Relationship between Terrorism, Tourism Sector, and Economy .... 10

2.3 The Effect of Terrorist Activities on Financial Markets........................ 13

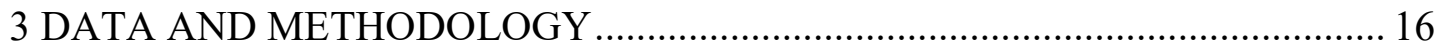

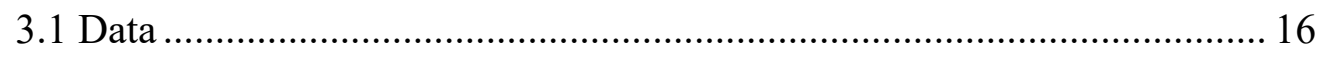

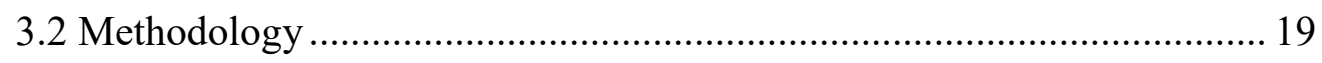

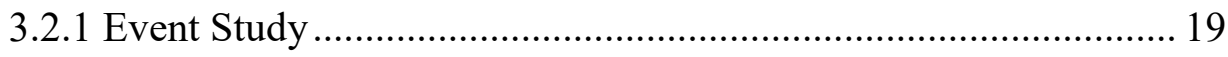

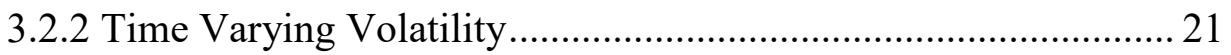

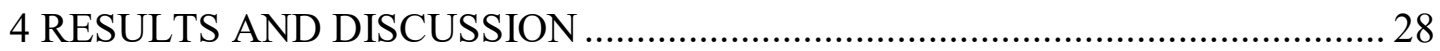

4.1 The Effect of Terror on Tourism Firms' Stock Returns ......................... 28

4.2 The Effect of Terror on Tourism Firms' Stock Returns Volatility........... 37 


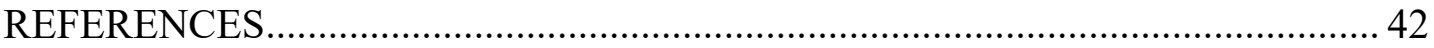

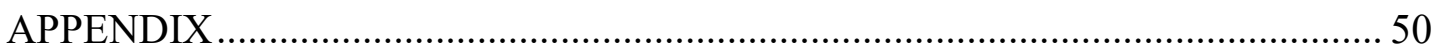

Appendix A: First Page the Publication of this Thesis in the Journal of

Current Issues in Tourism. 51 


\section{LIST OF TABLES}

Table 1: World's top ten tourist destinations (World Tourism Organization, 2018)... 9

Table 2: Tourism firm indices and stock market indices

Table 3: Summary of terrorist incidents .......................................................... 17

Table 4: Descriptive statistics and ARCH effects of the tourism indices returns...... 22

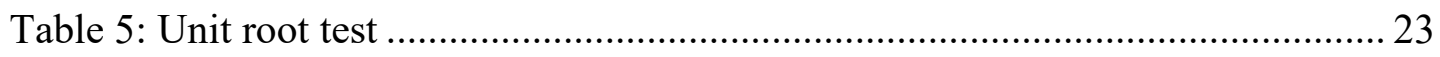

Table 6: The reaction of the tourism index returns to the terrorist incidents using market model of event study. 29

Table 7: The reaction of tourism index returns to the terrorist incidents using mean adjusted model of event study...... .33

Table 8: AARs and CAARs and their corresponding Generalized Sign test results . 35

Table 9: Conditional volatility and the impact of terrorist incidents on the indices.. 39 


\section{LIST OF FIGURES}

Figure 1: World's international tourism receipts (billion \$) ................................... 8

Figure 2: World's international tourist arrivals (millions) .................................... 9

Figure 3: The abnormal returns over the event window ...................................... 32

Figure 4: Average abnormal returns and cumulative average abnormal returns over

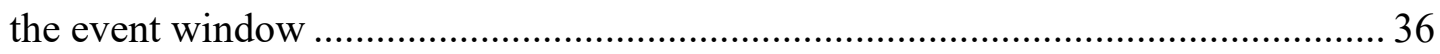




\section{LIST OF ABBREVIATIONS}

$\begin{array}{ll}\text { AAR } & \text { Average Abnormal Returns } \\ \text { AR } & \text { Abnormal Returns } \\ \text { ARCH } & \text { Autoregressive Conditional Heteroscedasticity } \\ \text { CAAR } & \text { Cumulative Average Abnormal Return } \\ \text { CAR } & \text { Cumulative Abnormal Return } \\ \text { EGARCH } & \text { Exponential Generalized Autoregressive Conditional } \\ & \text { Heteroscedasticity } \\ \text { EMH } & \text { Efficient Market Hypothesis } \\ \text { GARCH } & \text { Generalized Autoregressive Conditional Heteroscedasticity } \\ \text { GDP } & \text { Gross Domestic product } \\ \text { LR } & \text { Likelihood Ratio } \\ \text { MENA } & \text { Middle East and North Africa } \\ \text { TLG } & \text { Tourism-lead Growth }\end{array}$




\section{Chapter 1}

\section{INTRODUCTION}

\subsection{The Study's Background}

International tourism activities increased considerably during the last two decades reflecting the growth of the world economy. The tourism sector is interrelated to the overall economic growth through various channels. Tourism sector connected to over 180 supply-side activities (e.g. transportation, communication, accommodations, banking and finance, cultural and attractions services, and promotion services) where identified by the United Nations World Tourism Organization. Therefore, tourism has become an increasingly important economic factor for a number of developing countries (Tang and Abosedra, 2014). International tourism is regarded as a nonstandard type of export since it implies a source of receipts and consumption in situ. Given the difficulties in measuring tourism activity, the economic literature tends to focus on primary and manufactured product exports, hence neglecting this economic sector (Brida, Cortes-Jimenez, and Pulina, 2016). Katircioglu (2009a; 2009b) argues that international tourism generates tax revenues that can help governments overcome their budget deficits; it also generates export revenues that can offset the current account deficits and the negative balance of payment. The tourism sector creates employment, induces investment in human capital and technology, and stimulates the efficiency of local firms through increasing competition (Shahzad, Shahbaz, Ferrer, \& Kumar, 2017). 
It has been claimed that terrorism poses a serious threat to the economic performance of countries; for example, several studies have drawn attention to the significant adverse effects of terrorist attacks on economies (Feridun, 2011). Agnew (2010) describes terrorism as encompassing violent, criminal actions that target innocent, ordinary civilians, backed by social, political, and religious motives. From another point of view, Llussá and Tavares (2011) argue that "terrorism ranges from ethnically motivated to state-sponsored, from religious to ideologically motivate; it can directly target the government, the military or the civilian population, assassinate individuals or threaten the use of weapons of mass destruction". It has been exhibited in the economics literature that terrorist incidents are significantly volatile and scarce events across countries where rich countries are most likely to be targeted and with respect to their frequency over time. Moreover, the economic costs of terrorism activities may raise with persistency or geographically concentration of the attacks. Though, poor countries or those which targeted less by terror are hurt more by incidents.

Terrorism has become a major concern for the tourism industry, tourists, and host communities. Terrorism has been described as a significant barrier to international travel by creating fear and insecurity. Rationally, in the places where terrorist incidents executed and damaged the destination's image, the tourism demand declines. Tourists can easily alter their destination to a safer place. The more severe and the more frequent the terrorist attack is the greater is the inverse impact on tourist demand due to the higher perceived risk (Liu \& Pratt, 2017). Bassil, Saleh, and Anwar (2019) argue that frequent terrorist activities can influence tourists' decisions to visit a destination. The authors further argue that in addition to a loss of 
revenue and decreased international tourists, terrorism incurs enormous costs on tourism, which mainly include costs involving advertising to revive the once positive image of the destination, strengthening security to hinder future attacks, and rebuilding the destroyed venues and national landmarks. In addition, as Bassil et al., (2019) argue, high cost of terrorism can be in three forms; (1) additional advertising expenses to reduce the tarnished reputation of the tourism destination, (2) additional security-related expenses to hinder the potential attacks, (3) additional construction cost to repair the damaged venues. Indeed, not only tourism demand but the supply side is also very vulnerable to extreme events such as terrorism and other political violence (Ryan, 1993).

Based on the Efficient Market Hypothesis (EMH) (Fama et al., 1969), as the result of any new information (unanticipated) becomes available, investors evaluate the implications of such events on current and future individual stock prices immediately. Consequently, this new assessment fluctuates the stock prices to adjust either positively or inversely attributing to the influences of the occurred incident. Stock prices reflect investors' hopes and fears concerning the future earnings. Considering the high level of liquidity of stock markets, when unexpected information such as terrorist incident or other disasters emerges, investors may be induced to flee the market and looking for a safer or more sustainable market (Arin, Ciferri, and Spagnolo, 2008). Decisions to buy and sell can quickly, easily, and inexpensively, be reversed in reaction to such events. This initial panic can last for a long time or reverse if investors' hope returns back (Chen and Siems, 2004). 
Moreover, the market reaction can vary across various financial markets. Essaddam and Karagianis (2014) report that terrorism risk is a significant factor demonstrating the stock return volatility. Developed countries, however, haven't taken into consideration terrorist risk. This, though, is not the case for developing markets were the terrorist activities appear frequently and the financial markets seem to be adapted to unexpected occurrences. New terrorist activities then do not increase the level of uncertainty in developing markets.

The implications of terrorist incidents may vary across industries as well as based on the nature of the attacks. Brounen and Derwall (2010) report that financial market securities' reactions are stronger to domestic attacks than international terrorist attacks and generally, these effects last for a short period. Another point of view declared by Goel, Cagle, and Shawky (2017) as they argue that even though terrorism has a high emotional impact on investors, there is a limited material impact on the overall markets in general. While a specific company or industry may get economically impacted by a terrorist incident by a large amount, the market stays unimpacted. The authors believe that the high frequency of terrorist incidents and extensive media coverage has desensitized the public to terrorist incidents. In rare cases, the psychological impact may be so severe as to impact the long-term mood of investors.

The tourism industry, in particular, is highly vulnerable to terrorist attacks and natural disasters (Koshteh, 2018). Although having a tourism crisis management plan can hardly prevent terrorist activities or aid in capturing terrorists, the firms are advised to prepare a marketing and managerial plan, for example, to be able to deal 
effectively with such incidents and recover any ensuing losses (Sönmez, Apostolopoulos, \& Tarlow, 1999). In their review of hotels' readiness and crisis management, AlBattat and Mat Som (2013) discovered that, compared to low prices, tourists tend to give priority to safety and security; they added that although hotels are investing considerably in protective equipment, terrorists are increasingly becoming more organized. Over the past two decades, the subsectors of tourism, travel and leisure industries such as airports, commercial aircraft, hotels, public mass transportation systems, restaurants, cruise liners, leisure venues, and nightclubs became ideal targets of choice, with attacks causing an extensive loss of human life, including tourists (Zopiatis et al., 2018). Considerable empirical studies in the relevant literature examine the effect of terrorist incidents across various industries which will be reviewed in detail in next chapter such as (Kollias, Papadamou, and Stagiannis (2011); Chesney, Reshetar, and Karaman (2011)).

Furthermore, the market value of the tourism firms, which is represented by their stock prices, is the current value of the future cash flows (earnings). Shiller, Fischer, and Friedman (1984) argue that "mass psychology may well be the dominant cause of movements in the price of the aggregate stock market". Therefore, terrorist incidents make the investors anxious about the future earnings of the tourism firms, which force them to sell their stocks immediately, mainly because they expect a decline in the future, earnings of the firms. This consequently decreases the market value of the tourism companies and increases the volatility of the stock returns. In short, firms in the tourism industry tend to be more responsive to terror activities than their counterparts from other industries. 


\subsection{Aim and Significance of the Study}

Given the significant influences of terrorism on the tourism industry, the present thesis aims to examine the examined the impact of terrorist attacks on the stock returns and volatility of tourism companies in the top ten tourist destination countries in the world. This study proposes that the performance of the travel and leisure companies such as hotels, lodgings, gambling centers, and airlines are at least partially reliant on foreign travelers. Terrorist incidents are inversely affecting the growth of the tourism industry by, for example, lowering the tourism receipts locally and internationally.

The empirical studies thus far have broadly examined the impact of terror on the financial markets. In the hospitality literature, however, there are very few studies that have probed the impact of terror on the hospitality companies; these are confined to the hotel industry, ignoring other segments of the tourism industry, and to the specific terror attacks (e.g. 9/11) or limited countries (e.g. the United States or Taiwan). The overall aim of this study is to provide a complete picture of the impact of the local terrorist incidents on the stock returns and volatility of the tourism companies and to propose several hedging strategies and diversification investment opportunities.

This study fills a significant gap in the growing tourism literature by providing novel and comprehensive empirical evidence, using event study methodology, of the specific effects of terrorist incidents on the stock returns and volatility of the tourism companies in the ten leading tourist destination countries. To the best of our knowledge, this is the first study that uses the event study approach to examine 
terrorism and tourism stock markets and volatility. Thus, we believe that the results of this study will shed fresh light on the existing literature on hospitality.

\subsection{The Study's Structure}

The rest of this paper is organized as follows. In Chapter 2, the most recent and relevant literature is reviewed. In Chapter 3, the sample data and the examined terrorist incidents are described. In addition, the methods of estimations are introduced. In Chapter 4, the results of the analyses are presented and discussed. In Section 5, we conclude the study. 


\section{Chapter 2}

\section{REVIEW OF LITERATURE}

\subsection{World's Top Tourist Destinations}

As reported by (World Bank, 2018) and exhibited in Figure 1 and 2, world's tourism sector is growing dramatically, in particular, over the past two decades crossing 1.3 trillion dollars tourism receipts and 1.4 billion international tourist arrivals. Currently, the business volume equals or even exceeds oil export, food or automobiles productions. This global spread of tourism in industrialized and developed states has produced economic and employment benefits in many related sectors - from construction to agriculture or telecommunications (World Tourism Organization, 2019).

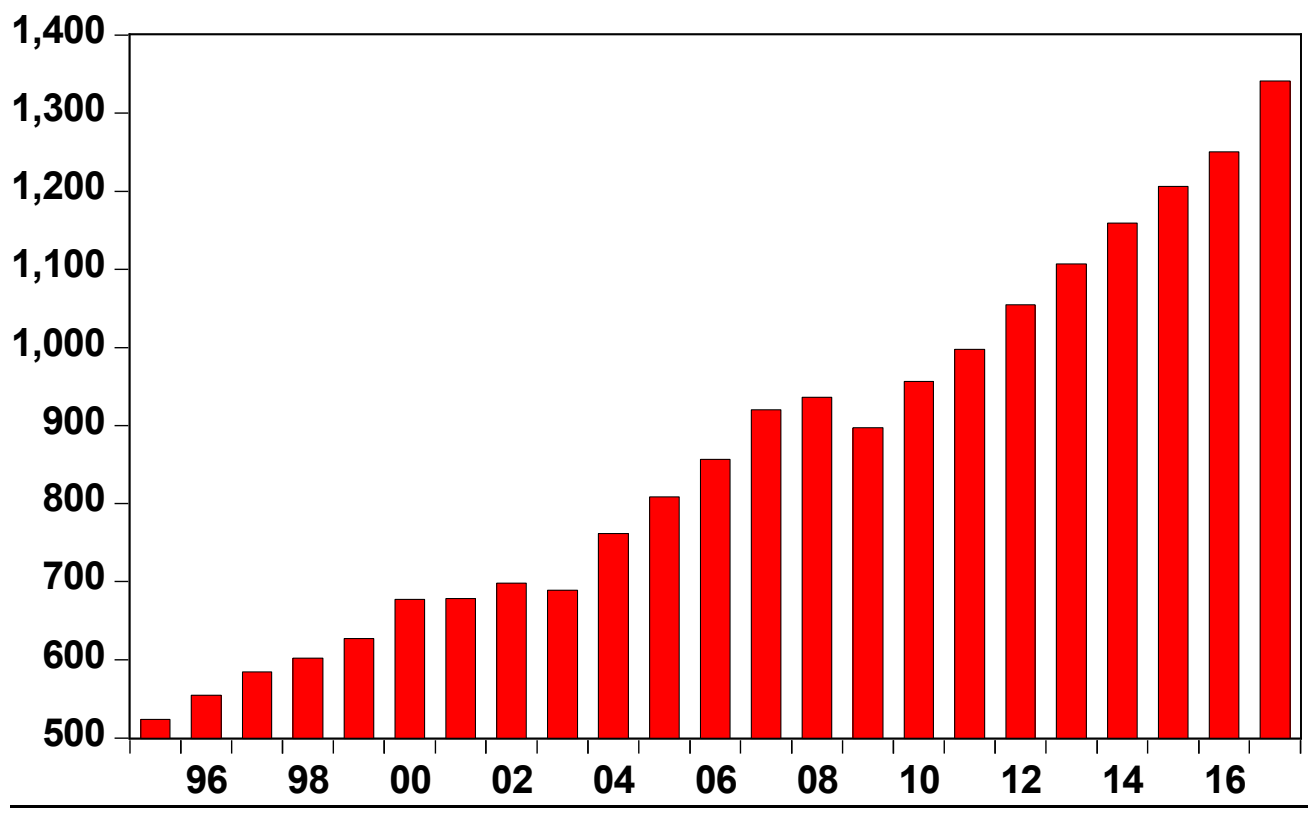

Figure 1: World's international tourism receipts (billion \$) 


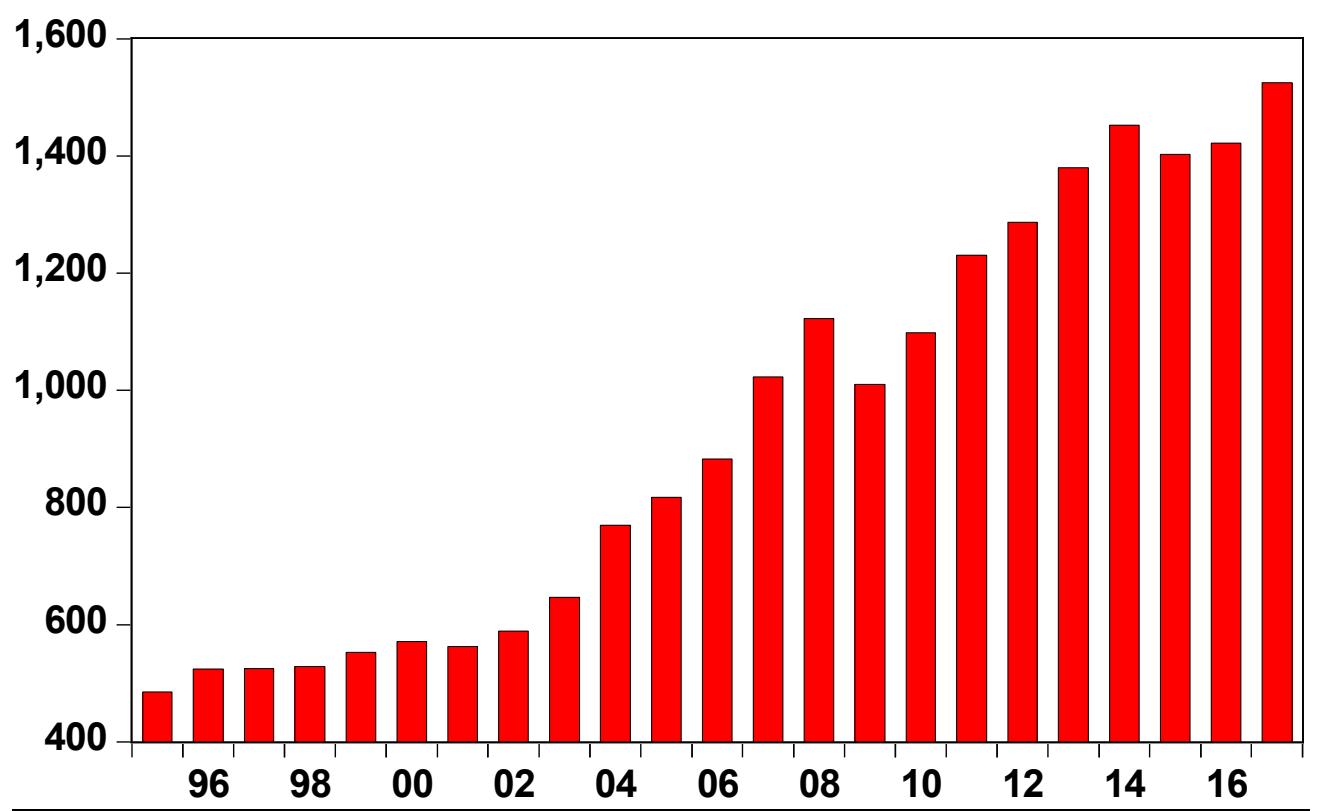

Figure 2: World's international tourist arrivals (millions)

In Table 1, when ranking the world's top leading tourism destinations, it is important to consider both international tourist arrivals and international tourism receipts. Seven out of the top ten destinations appear on both lists, despite showing marked differences in terms of the type of tourist they attract, as well as the average length of stay and spending per trip and the night.

Table 1: World's top ten tourist destinations (World Tourism Organization, 2018)

\begin{tabular}{|c|c|c|c|c|c|}
\hline \multicolumn{3}{|c|}{ International Tourist Arrivals (million) } & \multicolumn{3}{|c|}{$\begin{array}{c}\text { International Tourism Receipts } \\
\text { (US\$ billion) }\end{array}$} \\
\hline Rank & Destination & Volume & Rank & Destination & Volume \\
\hline 1 & France & 86.9 & 1 & USA & 210.7 \\
\hline 2 & Spain & 81.8 & 2 & Spain & 68 \\
\hline 3 & USA & 76.9 & 3 & France & 60.7 \\
\hline 4 & China & 60.7 & 4 & Thailand & 57.5 \\
\hline 5 & Italy & 58.3 & 5 & United Kingdom & 51.2 \\
\hline 6 & Mexico & 39.3 & 6 & Italy & 44.2 \\
\hline 7 & United Kingdom & 37.7 & 7 & Australia & 41.7 \\
\hline 8 & Turkey & 37.6 & 8 & Germany & 39.8 \\
\hline 9 & Germany & 37.5 & 9 & Macao (China) & 35.6 \\
\hline 10 & Thailand & 35.4 & 10 & Japan & 34.1 \\
\hline
\end{tabular}




\subsection{The Relationship between Terrorism, Tourism Sector, and}

\section{Economy}

Among the numerous studies that have empirically examined the tourism-led growth (TLG) hypothesis, the amount of evidence that supports the theory is far greater than that which refutes it (De Vita and Kyaw, 2016). Many studies have, in particular, documented the significantly positive effects of tourism growth on real income growth (Shahzad et al., 2017; Katircioglu, 2009a, 2010, 2011; Gunduz and Hatemi-J, 2005), in contrast to very few ones that have failed to draw such a conclusion (Katircioglu, 2009b). By reviewing almost 100 papers on TLG hypothesis, Brida et al., (2016) conclude that within a few exceptions all reviewed papers confirm the validity of TLG hypothesis that's promoting tourism activities can drive economic growth. Using quantile-on-quantile approach, Shahzad et al., (2017) examine the effect of tourism development on economic growth in top ten tourist destination in the world namely China, France, Germany, Italy, Mexico, Russia, Spain, Turkey, the United Kingdom, and the United States). The overall findings suggest the validity of TLG hypothesis. Tang and Tan (2017) test the validity of TLG for Malaysia using annual data covering the period of 1975 to 2011 and multivariate model. The findings support the validity of the theory that's tourism development has a positive impact on Malaysia's economic growth both in the short-run and in the long-run. In contrast to most of the relevant studies in literature, Katircioglu (2009b) empirically tested the validity of the TLG hypothesis for Turkey by using the bounds test and the Johansen technique for cointegration. Results suggest that the TLG hypothesis cannot be inferred for Turkey since both the bounds and the Johansen tests do not confirm the long-term equilibrium relationship between international tourism and economic growth (real GDP). 
The economic costs of terrorist attacks have been extensively studied by many scholars since the past century. The impact of terrorism extends to the major economic sectors in the countries that are internally exposed to such attacks (Jawabreh, Bader, \& Saleh, 2018). For example, Llussá and Tavares (2011) evaluate the cost of various kinds of terrorist incidents on the growth output and its components. The study reports that private consumption and investment are significantly and negatively affected by terror attacks. From the external perspective, Enders and Sandler (1996) claim that terrorist attacks in Spain and Greece impacted foreign direct investment. On the same note, Enders, Sachsida, and Sandler (2006) examine the extent to which transnational terrorist incidents impact foreign direct investment and found that the terrorist attacks affected the U.S. stocks opportunities for foreign direct investment in the countries that work with the United States. Abadie and Gardeazabal (2008) used an economic model to investigate whether terrorism may have a large effect on the allocation of productive capital across countries. The study reveals that changes in the intensity of terrorism may cause large movements of capital across countries if the world economy is sufficiently open, so international investors are able to diversify other types of country risks.

The tourism literature contains a considerable number of (recent) empirical studies on the effects of terrorism on tourism, reiterating the adverse effects of terrorism on the growth of the tourism industry (e.g. Ahlfeldt, Franke, \& Maennig, 2015; Araña \& León, 2008; Bassil et al., 2019; Cró \& Martins, 2017; Feridun, 2011; Liu \& Pratt, 2017; Raza \& Jawaid, 2013). 
Arna and Leon (2008) investigate the short-run implications of the September 11 attacks on the Mediterranean and Canary Iceland. The study reports a significant decrease in tourists' utility for those deciding upon travel plans for both Mediterranean and Canary destinations. On the same note, while investigating the relationship between terrorism and tourism sector Ahlfeldt et al., (2015) draw the same conclusion. Examining terrorism and tourism demand relationship in Lebanon, Turkey, and Israel, Bassil et al., (2019) reveal terrorism in one country affects visitor arrivals not only to that country but also to other countries. In addition, the study shows that the reaction of tourism demand to terrorist activities varies across sample counties. On the same framework, Cró \& Martins (2017) study the implications of tourism disasters and crises including terrorism on the tourism sector in 25 countries and Madeira Island using the structural break technique. The study provides evidence of the inverse reaction of tourism arrival demand to such shocks. Furthermore, Feridun (2011) examines the long-run and short-run causal effect of terrorist activities on the tourism sector in Turkey. The evidence obtained from the long-run and short-run parameter estimates indicates the existence of a negative causal effect of terrorism on tourism. Examining the influences of terrorism on the tourism industry in a place where terrorism has become a major and highly destructive phenomenon, Raza and Jawaid (2013), confirm terrorist activities lower tourism performance in Pakistan. Recently, comprehensive research by Liu and Pratt (2017) quantifies the relationship between terrorism and tourism in 95 different countries and territories. Overall findings suggest no long-run effect of terrorism on tourism sector while short-run effects were limited to 25 out of 95 countries implying the relicense of international tourism to terrorism. 


\subsection{The Effect of Terrorist Activities on Financial Markets}

A considerable number of empirical studies have used various approaches and with different objectives to investigate the effects of terrorist incidents on the stock market. Arin, Ciferri, and Spag-nolo (2008) have pointed out the significant effect of terrorist attacks on both the stock market and the stock market volatility in six countries; they further argue that the impact is greater in the emerging markets. Brounen and Derwall (2010) have found that the stock market and the industrial indices prices are more responsive to the local terrorist incidents and that the $9 / 11$ attacks alone left a long-term impact on the financial markets. Balcilar, Gupta, Pierdzioch, and Wohar (2018) examined the impact of local terrorist incidents on the stock markets of the G7 countries, namely Canada, France, Germany, Italy, Japan, the United Kingdom, and the United States as well as the impact of the terrorist attacks in the United States on the other G7 countries. The study provided strong evidence of the effect of the attacks on the stock market returns of all the G7 countries except France and Japan; they also found that the local terrorist incidents in the United States only affected Japan and the United Kingdom. On the same note, Mnasri and Nechi (2016) learned that the effect of terror on the stock market volatility in 12 Middle East and North Africa (MENA) countries was significant and its impact was likely to continue longer than the developed markets. Contrary to the previous studies, Aksoy and Demiralay (2017) pointed out that, despite the increasing terrorist attacks in Turkey, the incidents had the least impact on both the stock market and the foreign exchange market; however, they reported that the foreign investors were negatively influenced by the attacks. 
At the industrial level, in their examination of the impact on the financial markets in Spain and the United Kingdom of the Madrid and London bomb attacks in 2004 and 2005, Kollias, Papadamou, and Stagiannis (2011) found that, compared to the United Kingdom, the incidents caused far more negative abnormal returns across major sectors in the Spanish market. In another study on the impact of extreme events including terrorist incidents on the financial markets of 25 countries, Chesney, Reshetar, and Karaman (2011) discovered that the Swiss stock market was most severely affected compared to the American stock market, which was affected the least. The airline industry and the insurance sector exhibit the highest susceptibility to terrorism, while the banking industry shows the lowest vulnerability. In contrast to other studies, by studying the aftermath of the recent terrorist incidents in 11/13 Paris terrorist attacks on global defense industry, Apergis and Apergis (2016) reveal that this terrorist attacks event supports an upward trend in cumulative abnormal returns across all companies over the post-attack period, that's the attacks simply had a positive impact on defense companies.

The implications of terrorist incident events on airline industry have studied by Drakos (2004) and Kolaric and Schiereck (2016). The former documents a structural break in systematic risk (beta) for airline stocks. Moreover, their empirical evidence shows that, apart from the systematic risk, idiosyncratic risk has also substantially increased. The latter also reports a strong short term negative reaction of the largest U.S., Canadian, and European airline firms' stocks to the terrorist incidents in Paris and Brussel. 
The empirical studies thus far have broadly examined the impact of terror on the financial markets. In the hospitality literature, however, there are very few studies that have probed the impact of terror on the hospitality companies; these are confined to the hotel industry, ignoring other segments of the tourism industry, and to the specific terror attacks (e.g. 9/11) or limited countries (e.g. the United States or Taiwan). Using a sample of 35,000 hotels over ten years, Kosová and Enz (2012) examined the impact of the $9 / 11$ attacks and the 2008 financial crisis on the hotel industry. The findings suggest that both events had a significantly negative impact on the hotel industry; however, the effects of the terrorist incidents were far greater, albeit shorter, than the financial crisis. On the same note, Brounen and Derwall (2010) found that the airline and hotel indices responded negatively to the $9 / 11$ attacks; however, these responses are not statistically significant. Moreover, among several international extreme events, Chen (2011) attempted to capture the impact of the 9/11 attacks on the Taiwanese hotels. Using panel data methodology, the author learned that the 9/11 attacks significantly undermined the sales revenues of the hotels in Taiwan.

In the most relevant and recent study, Using econometric techniques Zopiatis, Savva, Lambertides, and McAleer (2018) examined the effects of 150 unexpected nonmacro incidents (e.g., terrorism, natural catastrophes, and war conflicts) on five global hospitality/ tourism stock indices. Overall findings of the study documented the impact of such events on hospitality/ tourism stock indices, with distinctive differences among the types and specificities of each event under investigation. 


\section{Chapter 3}

\section{DATA AND METHODOLOGY}

\subsection{Data}

Table 2 lists the countries for which the tourism sector indices from 1995 to 2017 have been available. The sample countries are ranked among the top ten world's tourist destinations, either according to international tourist arrivals or the international tourism receipts in the recent years (World Tourism Organization, 2017) ${ }^{1}$. In these countries, terrorist attacks have particularly occurred during the sample period ${ }^{2}$. The historical price data for the main stock market indices and the tourism stock indices were obtained from Thomson Reuters Datastream.

Table 2: Tourism firm indices and stock market indices

\begin{tabular}{lll}
\hline Countries & Tourism Stock Index & Market Index \\
\hline \multirow{2}{*}{ China } & FTSE China Travel \& Leisure & $\begin{array}{l}\text { Shanghai SE Composite } \\
\text { Index }\end{array}$ \\
France & CAC Travel \& Leisure & CAC 40 Index \\
& FTSE Germany Travel \& Leisure - & \\
Germany & Price Index & DAX Index \\
Spain & BCN 5 Commerce Leisure and Tourism & IBEX 35 Index \\
Thailand & Tour \& Leisure Index & SET Index \\
Turkey & BIST Tourism & BIST 100 Index \\
UK & FTSE 350 Travel \& Leisure & FTSE 100 Index \\
U.S. & Dow Jones Travel \& Leisure & S\&P 500 Index \\
\hline
\end{tabular}

\footnotetext{
${ }^{1}$ Russia is not included in the list of the countries due to a lack of tourism sector index. For France, the tourism stock index was active until February 2016.

${ }^{2}$ Italy is not included in the list, since there have been no major terrorist attacks in terms of human casualties after the introduction of the tourism sector index in the stock market.
} 
The terrorist incidents were obtained from Johnston's Archive Database. The archive provides a list of the selected terrorist attacks from 1880 to 2017 . The list includes attacks that resulted in 20 or more fatalities and/or 100 or more injuries; it also includes attacks other than those of special political significance (e.g. assassinations), significant attacks involving unconventional weapons, and some non-terrorist criminal acts of methodological relevance ${ }^{3}$. For the sample countries, the terrorist incidents that fit the definition of terrorist incidents are presented in Table 3.

Table 3: Summary of terrorist incidents

\begin{tabular}{|c|c|c|c|c|c|c|}
\hline Country & Event & $\begin{array}{c}\text { Incident } \\
\text { date }\end{array}$ & $\begin{array}{l}\text { Summary: Where? Who? } \\
\text { How? }\end{array}$ & Fatality & Wounded & $\begin{array}{c}\text { Human } \\
\text { casualties }\end{array}$ \\
\hline \multirow[t]{3}{*}{ China } & 1 & 5-Jul-09 & $\begin{array}{l}\text { Muslim Uighurs attacked Han } \\
\text { Chinese by knife, wood, and } \\
\text { stone in Urumqi, the capital of } \\
\text { China's northwest Xinjiang } \\
\text { region. }\end{array}$ & 184 & 1650 & 1834 \\
\hline & 2 & 26-Jun-13 & $\begin{array}{l}\text { Terrorists attacked a police } \\
\text { station by knife in Turpan, } \\
\text { Xinjiang, PR China. }\end{array}$ & 27 & 3 & 30 \\
\hline & 3 & 1-Mar-14 & $\begin{array}{l}\text { Eight terrorists attacked } \\
\text { passengers at a railway station } \\
\text { by knife in Kunming, PR China. } \\
\text { The attacks started at 21:20 }\end{array}$ & 33 & 143 & 176 \\
\hline \multirow[t]{2}{*}{ France } & 1 & 24-Mar-15 & $\begin{array}{l}\text { The deliberate aircraft crash } \\
\text { near the Riviera, Nice; contact } \\
\text { ended at } 10.53 \text { a.m. }\end{array}$ & 150 & 0 & 150 \\
\hline & 2 & 13-Nov-15 & $\begin{array}{l}\text { Six attacks by ISIS by shooting } \\
\text { and suicide bombings in Paris; } \\
\text { the first attack started at } 9.16 \\
\text { p.m. }\end{array}$ & 137 & 352 & 489 \\
\hline Germany & 1 & 19-Dec-16 & $\begin{array}{l}\text { A truck drove into a } \\
\text { supermarket in Berlin by ISIS. } \\
\text { The attack took place at } 8 \text { a.m. } \\
\text { and was followed by more } \\
\text { attacks in the next few days. }\end{array}$ & 12 & 56 & 68 \\
\hline \multirow[t]{2}{*}{ Spain } & 1 & 11-Mar-04 & $\begin{array}{l}\text { Madrid train bombing attacks } \\
\text { by al-Qaeda at } 7.37 \text { a.m. }\end{array}$ & 191 & 1876 & 2067 \\
\hline & 2 & 17-Aug-17 & $\begin{array}{l}\text { A truck attack by ISIS in } \\
\text { Barcelona at } 4.56 \text { p.m. }\end{array}$ & 14 & 130 & 144 \\
\hline Thailand & 1 & 17-Aug-15 & $\begin{array}{l}\text { A blast in Bangkok at } 6.55 \\
\text { p.m.; most of the victims were } \\
\text { foreign tourists. }\end{array}$ & 21 & 121 & 142 \\
\hline \multirow[t]{2}{*}{ Turkey } & 1 & 20-Nov-03 & $\begin{array}{l}\text { Suicide bombers attacked the } \\
\text { British consulate and HSBC } \\
\text { bank HQ in Istanbul at 11:10 } \\
\text { a.m. }\end{array}$ & 30 & 400 & 430 \\
\hline & 2 & 11-May-13 & $\begin{array}{l}\text { Two car bombings near a town } \\
\text { hall and post office in Reyhanli; }\end{array}$ & 46 & 100 & 146 \\
\hline
\end{tabular}

\footnotetext{
${ }^{3}$ For more information on the list and the criteria, see http://www.johnstonsarchive.net/terrorism/wrjp255b.html, accessed on March 30, 2018.
} 


\begin{tabular}{|c|c|c|c|c|c|c|}
\hline & 3 & 20-Jul-15 & $\begin{array}{l}\text { A suicide bomber attacked a } \\
\text { socialist youth group in the } \\
\text { Suruc district of Şanliurfa } \\
\text { Province. }\end{array}$ & 32 & 100 & 132 \\
\hline & 4 & $10-O c t-15$ & $\begin{array}{l}\text { Two suicide bombings at a } \\
\text { political rally outside Ankara } \\
\text { central train station }\end{array}$ & 102 & 400 & 502 \\
\hline & 5 & 17-Feb-16 & $\begin{array}{l}\text { A suicide car bombing near } \\
\text { military bases in Ankara }\end{array}$ & 28 & 61 & 89 \\
\hline & 6 & 13-Mar-16 & $\begin{array}{l}\text { A car bombing took place in } \\
\text { Kizilay, Ankara. }\end{array}$ & 38 & 125 & 163 \\
\hline & 7 & 28-Jun-16 & $\begin{array}{l}\text { Shooting and a suicide bombing } \\
\text { by three terrorists at Ataturk } \\
\text { airport in Istanbul }\end{array}$ & 47 & 239 & 286 \\
\hline & 8 & 20-Aug-16 & $\begin{array}{l}\text { ISIS suicide bombing of a } \\
\text { wedding party in Gaziantep } \\
\text { City }\end{array}$ & 57 & 90 & 147 \\
\hline & 9 & 10-Dec-16 & $\begin{array}{l}\text { Two suicide bombings near a } \\
\text { football stadium in Istanbul's } \\
\text { Beşiktaş municipality }\end{array}$ & 38 & 166 & 204 \\
\hline & 10 & 1-Jan-17 & $\begin{array}{l}\text { Shooting at a nightclub during } \\
\text { New Year's celebrations in } \\
\text { Istanbul }\end{array}$ & 39 & 69 & 108 \\
\hline \multirow[t]{4}{*}{ UK } & 1 & 15-Jun-96 & $\begin{array}{l}\text { IRA truck bomb exploded at a } \\
\text { shopping center in Manchester, } \\
\text { England, at } 11.17 \text { a.m. }\end{array}$ & 0 & 206 & 206 \\
\hline & 2 & 15-Aug-98 & $\begin{array}{l}\text { Two Omagh bombings in } \\
\text { Northern Ireland, UK at } 3.10 \\
\text { p.m. }\end{array}$ & 29 & 530 & 559 \\
\hline & 3 & 7-Jul-05 & $\begin{array}{l}\text { Four suicide bombing attacks } \\
\text { targeted the subway in London } \\
\text { between } 8.49 \text { and } 9.47 \text { a.m. }\end{array}$ & 56 & 784 & 840 \\
\hline & 4 & 22-Mar-17 & $\begin{array}{l}\text { A vehicle attack on the } \\
\text { Westminster Bridge, after } \\
\text { which the terrorist stabbed and } \\
\text { killed a police officer before } \\
\text { being shot and killed. The } \\
\text { incident occurred at } 2.40 \text { p.m. }\end{array}$ & 7 & 49 & 56 \\
\hline \multirow[t]{6}{*}{ U.S. } & 1 & 31-Oct-99 & $\begin{array}{l}\text { The deliberate crash of Egypt } \\
\text { Air plane off Nantucket Island } \\
\text { by copilot at } 1.42 \text { a.m. }\end{array}$ & 217 & 0 & 217 \\
\hline & 2 & 11-Sep-01 & $\begin{array}{l}\text { The crash of several hijacked } \\
\text { planes into the World Trade } \\
\text { Center towers, Pentagon, and } \\
\text { the rural area of Pennsylvania } \\
\text { between } 8.46 \text { and } 10.28 \text { a.m. }\end{array}$ & 2993 & 8900 & 11893 \\
\hline & 3 & 16-Apr-07 & $\begin{array}{l}\text { (Criminal) shooting attack at } \\
\text { Virginia Polytechnic Institute at } \\
7.15 \text { a.m. }\end{array}$ & 33 & 17 & 50 \\
\hline & 4 & 14-Dec-12 & $\begin{array}{l}\text { (Criminal) shooting attack at } \\
\text { elementary school in Nickel } \\
\text { Mines, Pennsylvania, at } 9.35 \\
\text { a.m. }\end{array}$ & 28 & 3 & 31 \\
\hline & 5 & 12-Jun-16 & $\begin{array}{l}\text { Shooting at a nightclub in } \\
\text { Orlando, Florida, at } 2.02 \mathrm{a} . \mathrm{m} \text {. }\end{array}$ & 50 & 53 & 103 \\
\hline & 6 & 1-Oct-17 & $\begin{array}{l}\text { A sniper attack on a concert in } \\
\text { Las Vegas, Nevada, at } 10.05 \\
\text { p.m. }\end{array}$ & 59 & 527 & 586 \\
\hline Total & 29 & & & 4698 & 17150 & 21848 \\
\hline
\end{tabular}

Notes: In Turkey, the first terrorist incident (1) was included in the event study and the other events did not meet the criteria for the event study methodology. For the volatility analysis, all the terrorist incidents were included. 


\subsection{Methodology}

\subsubsection{Event Study}

Event study is a well-known methodology that captures the impact of a particular event on the stock returns. McWilliams and Siegel (1997) argue that, in the event studies, the event must be clearly defined and its impact must be theoretically justified. Furthermore, they argue that the event study methodology incorporates three assumptions: (a) markets are efficient, (b) the event is unexpected by the market, and (c) there are no other confounding events over the event window. It is expected that, on average, the tourism indices react negatively to terrorist incidents.

In their event study on terrorist incidents, Goel, Cagle, and Shawky (2017) considered the terrorist attacks as purely unanticipated events or new information. The expected cost and benefit of the new information are normally reflected in the stock value adjustment after the event (Brown \& Warner, 1985). In this study, it was confirmed that there was no confounding event during the event window, and there had been no other terrorist incidents for at least six months prior to the examined terrorist incidents surrounding the event window.

In this study, the standard event study methodology, namely the standard market model and mean adjusted return models (MacK-inlay, 1997) were used to measure the reaction of the tourism indices to the terrorist incidents. The estimation period for the event study was from -21 to -255 days and the event window was from -20 to + 20 days, relative to event (incident) day (0). During the event window, the study focused on the reaction of the tourism indices for event day 0 and event day period + 1 (i.e. $(0,+1))$ as well as the post and longer event periods of $+2,+5$, and +10 days, 
relative to the event day (i.e. $(0,+2),(0,+5)$, and $(0,+10))$. For the events that happened on a holiday or not during the stock market trading days, the subsequent first trading day was considered the event day. Adopting the market model, the below equation used to estimate the expected returns.

$R_{i t}-R_{r f, t}=\mu+\beta\left[M K T-R F_{t}\right]+\varepsilon_{i t}$

Where $R_{i t}-R_{r f, t}$ is actual an return on sector $i$ in excess of the 1- month Treasury bill rate, $M K T-R F_{t}$ is return on thea market portfolio which is calculated as the value-weighted return of all CRSP stocks incorporated in the U.S. in excess of the 1month Treasury bill rate and $\varepsilon_{i t}$ is the idiosyncratic error term which assumed to be approximately normally distributed. Hence, the abnormal return is calculated as follow.

$A R_{i t}=\left[R_{i t}-R_{r f, t}\right]-\mu-\beta\left[M K T-R F_{t}\right]-\varepsilon_{i t}$

Where $A R_{i t}$ is the abnormal return of index $i$ on the incident date $t$. Parametric tstatistics was used to test the statistical significance of abnormal returns (ARs) and cumulative abnormal returns (CARs). Mean adjusted return model of event study, however, follows the below equation in this study.

$A R_{i t}=R_{t}-\hat{R}$

Where $A R_{i t}$ is the abnormal return of index $i$ on the_incident date $t$. Rt is actual an return on sector $i$ in excess of the 1 - month Treasury bill rate, and $\hat{R}$ is the mean of 
this index daily return in the $(-50,-11)$ estimation period. Furthermore, the cumulative abnormal return is calculated as.

$$
C A R_{i t}=\sum_{t=T 1}^{T 2} A R t
$$

Where, $T 1$ is the event day and $T 2$ is consequently $1,2,5$, and 10 days following the event. In addition, the non-parametric Generalized Sign Test (G-sign test) was used to test whether the fraction of the non-positive average abnormal returns (AARs) and the cumulative average abnormal returns (CAARs) of tourism indices were statistically significant (Cowan, 1992). Finally, this study also counted the number of the trading days that it took for the tourism sector index to return to the pre-attack level (Chen \& Siems, 2004).

\subsubsection{Time Varying Volatility}

Table 4 shows the descriptive statistics and test results of the autoregressive conditional heteroscedasticity $(\mathrm{ARCH})$ effects. As it can be seen, all the series are leptokurtic that is the kurtosis are even greater than 4 . Moreover, as a starting point to examine the volatility, the presence of $\mathrm{ARCH}$ effects is examined by adopting the ARCH test. Obviously, for all eight countries the null hypothesis of no ARCH effects is rejected at the $1 \%$ level of significance except for the case of France which rejected at $5 \%$ level of significance.

Further, as presented in Table 5, all the series were found to be stationary, as they were already in their first difference form. Since the ARCH effects were confirmed, the time-varying volatility models could then be formulated in the next step. 
Table 4: Descriptive statistics and ARCH effects of the tourism indices returns

\begin{tabular}{|c|c|c|c|c|c|c|c|c|}
\hline Country & Time span & Mean & SD & Skewness & Kurtosis & $\begin{array}{l}\text { Jarque } \\
\text {-Bera }\end{array}$ & Prob. & ARCH effect \\
\hline China & $\begin{array}{l}\text { 02.Jan.2008- } \\
\text { 30.Dec.2016 }\end{array}$ & $-6.83 \mathrm{E}-0$ & 0.0224 & -0.5043 & 5.91 & 869.3 & 0.000 & $(88.4)^{* * *}$ \\
\hline France & $\begin{array}{l}\text { 02.Jan.2012- } \\
\text { 12.Feb.2016 }\end{array}$ & 0.000491 & 0.0111 & -0.2870 & 4.61 & 129.2 & 0.000 & $(3.83) * *$ \\
\hline Germany & $\begin{array}{l}\text { 02.Jan.2015- } \\
\text { 29.Dec.2017 }\end{array}$ & 0.001247 & 0.0195 & -0.2780 & 5.51 & 208.4 & 0.000 & $(15.6) * * *$ \\
\hline Spain & $\begin{array}{l}\text { 02.Jan.2003- } \\
\text { 29.Dec.2017 }\end{array}$ & 0.000113 & 0.0423 & 25.677 & 956.7 & 1450 & 0.000 & $(223) * * *$ \\
\hline Thailand & $\begin{array}{l}\text { 02.Jan.2013- } \\
\text { 30.Dec.2016 }\end{array}$ & 0.000476 & 0.0152 & -0.257 & 6.502 & 510.7 & 0.000 & $(17.6) * * *$ \\
\hline Turkey & $\begin{array}{l}\text { 04.Jan.2000- } \\
\text { 29.Dec.2017 }\end{array}$ & 0.000613 & 0.0287 & 0.6932 & 12.22 & 1659 & 0.000 & $(796) * * *$ \\
\hline UK & $\begin{array}{l}\text { 02.Jan.1995- } \\
\text { 29.Dec.2017 }\end{array}$ & 0.000264 & 0.0124 & -0.3138 & 7.248 & 4466 & 0.000 & $(1071) * * *$. \\
\hline U.S. & $\begin{array}{l}\text { 02.Jan.1998- } \\
\text { 29.Dec.2017 }\end{array}$ & 0.000431 & 0.0137 & -0.3335 & 9.784 & 9748 & 0.000 & $(116.2) * * *$ \\
\hline
\end{tabular}

Note: (A) The ARCH effect value is Obs*R-squared. (B) ** \& *** represent the rejection of null hypothesis (no ARCH effect) at $5 \%$ and $1 \%$ levels of significance, respectively.

The series are examined for stationarity to investigate whether mean, variance, and covariance are steady over time. To conduct the stationarity test, this thesis relies on Augmented Dikey-Fuller (ADF) and Philip-Peron (pp) approaches. As it can be observed, the series of the return of tourism and market indices for all sample countries are stationary. 
Table 5: Unit root test

\begin{tabular}{|c|c|c|c|c|}
\hline Indices & Criteria & $\tau_{\mu}$ & $\tau_{\mathrm{T}}$ & $\tau$ \\
\hline France Tourism Index & $\mathrm{ADF}$ & $-32.07^{*}$ & $-32.13 *$ & $-32.03 *$ \\
\hline France Tourism Index & PP & $-32.14^{*}$ & $-32.25 *$ & $-32.07 *$ \\
\hline France Market Index & $\mathrm{ADF}$ & $-34.33^{*}$ & $-34.37^{*}$ & $-34.33 *$ \\
\hline France Market Index & $\mathrm{PP}$ & $-34.45^{*}$ & $-34.51 *$ & $-34.44 *$ \\
\hline China Tourism Index & $\mathrm{ADF}$ & $-43.70 *$ & $-43.72 *$ & $-43.71 *$ \\
\hline China Tourism Index & PP & $-43.65^{*}$ & $-43.66^{*}$ & $-43.66^{*}$ \\
\hline China Market Index & $\mathrm{ADF}$ & $-45.61 *$ & $-45.65 *$ & $-45.62 *$ \\
\hline China Market Index & PP & $-45.61 *$ & $-45.64 *$ & $-45.62 *$ \\
\hline Germany Tourism Index & $\mathrm{ADF}$ & $-26.83^{*}$ & $-27.01 *$ & $-26.74 *$ \\
\hline Germany Tourism Index & PP & $-26.83^{*}$ & $-27.01^{*}$ & $-26.74 *$ \\
\hline Germany Market Index & $\mathrm{ADF}$ & $-26.99 *$ & $-26.98 *$ & $-26.98^{*}$ \\
\hline Germany Market Index & $\mathrm{PP}$ & $-27.02 *$ & $-27.00 *$ & $-26.99 *$ \\
\hline Spain Tourism Index & $\mathrm{ADF}$ & $-69.08 *$ & $-69.08 *$ & $-69.06^{*}$ \\
\hline Spain Tourism Index & PP & $-69.14^{*}$ & $-69.13 *$ & $-69.09 *$ \\
\hline Spain Market Index & $\mathrm{ADF}$ & $-60.93 *$ & $-60.94 *$ & $-60.92 *$ \\
\hline Spain Market Index & $\mathrm{PP}$ & $-61.35^{*}$ & $-61.37 *$ & $-61.33 *$ \\
\hline Thailand Tourism Index & $\mathrm{ADF}$ & $-31.63 *$ & $-31.63 *$ & $-31.62 *$ \\
\hline Thailand Tourism Index & PP & $-31.63^{*}$ & $-31.64 *$ & $-31.62 *$ \\
\hline Thailand Market Index & $\mathrm{ADF}$ & $-29.93 *$ & $-29.92 *$ & $-29.94 *$ \\
\hline Thailand Market Index & PP & $-29.91 *$ & $-29.89 *$ & $-29.90 *$ \\
\hline Turkey Tourism Index & $\mathrm{ADF}$ & $-58.91 *$ & $-58.91 *$ & $-58.89 *$ \\
\hline Turkey Tourism Index & PP & $-59.32 *$ & $-59.31 *$ & $-59.32 *$ \\
\hline Turkey Market Index & ADF & $-66.62 *$ & $-66.61 *$ & $-66.56^{*}$ \\
\hline Turkey Market Index & PP & $-66.62 *$ & $-66.61 *$ & $-66.56^{*}$ \\
\hline UK Tourism Index & $\mathrm{ADF}$ & $-34.27 *$ & $-34.29 *$ & $-34.23 *$ \\
\hline UK Tourism Index & PP & $-53.31 *$ & $-53.33 *$ & $-53.22 *$ \\
\hline UK Market Index & $\mathrm{ADF}$ & $-48.93 *$ & $-48.93 *$ & $-48.89 *$ \\
\hline UK Market Index & $\mathrm{PP}$ & $-49.19 *$ & $-49.18^{*}$ & $-49.23 *$ \\
\hline U.S. Tourism Index & ADF & $-51.81 *$ & $-51.82 *$ & $-51.74 *$ \\
\hline U.S. Tourism Index & PP & $-69.41 *$ & $-69.51 *$ & $-69.50 *$ \\
\hline U.S. Market Index & $\mathrm{ADF}$ & $-54.73 *$ & $-54.73 *$ & $-54.69 *$ \\
\hline U.S. Market Index & PP & $-77.50 *$ & $-77.52 *$ & $-77.30 *$ \\
\hline
\end{tabular}

Note: (A) Null Hypothesis: Data is not stationary. (B) Asterisk $(*)$ denotes 1\% significant level. (C) $\tau_{\mu}$ Represents the model with intercept and without trend, $\tau_{\mathrm{T}}$ represents the model with intercept and trend and $\tau$ is the model without intercept and trend. (D) Optimum lag lengths are selected using Schwartz Criterion. 
As noted earlier, in the context of the sample terrorist incidents of our study, as soon as the presence of the $\mathrm{ARCH}$ effects and stationarity of the series were confirmed for the stock returns of the sample tourism firms of all the countries, we then moved to the next step to investigate the impact of the terrorist incidents on the volatility of the sample stock returns. The Generalized Autoregressive Conditional Heteroscedasticity (GARCH) of Bollerslev (1986) and the Exponential Generalized Autoregressive Conditional Heteroscedasticity (EGARCH) model of Nelson (1991) have been employed to estimate the volatility of high frequency data such as stock returns by Herwartz (2017) and exchange rates by Tuna (2009).

The pioneer conditional volatility modelling belongs to Engle (1982), who introduced the Autoregressive Conditional Heteroscedasticity $(\mathrm{ARCH})$ model; this model examines the conditional volatility of a variable as a function of the variance of its lagged squared residuals. A few years later, Bollerslev (1986) developed a more comprehensive model, as an extension of the ARCH model, and called it GARCH this model examines the conditional volatility as the function of its variance in addition to its squared residuals. However, the GARCH model is restricted by the fact that it cannot measure the asymmetric effects of shocks. Nelson (1991) extended the GARCH model and developed a far more flexible model called EGARCH. Unlike GARCH, the EGARCH model can capture the asymmetric effects (leverage effect) to allow the negative and positive shocks of the same magnitude to have a differential impact on the conditional volatility which overcomes the drawback of GARCH model. Another advantage of the EGARCH model over the GARCH model is the log-linear form of the conditional variance equation, which allows the coefficients to be negative. This formulation is useful as the stock markets are 
evidenced to be affected more from bad news than good news of the same magnitude. The conditional variance equations for the GARCH $(1,1)$ and the EGARCH $(1,1)$ models are given by Equations 5 and 6 , respectively.

$$
\begin{aligned}
& h_{t}=\mu+\delta \varepsilon_{t-1}^{2}+\theta h_{t-1} \\
& \log \left(\mathrm{h}_{\mathrm{t}}\right)=\mu+\delta\left[\frac{\sigma_{\mathrm{t}-1}}{\sqrt{\mathrm{h}_{\mathrm{t}-1}}}\right]+\theta \log \left(\mathrm{h}_{\mathrm{t}-1}\right)+\gamma \frac{\varepsilon_{\mathrm{t}-1}}{\sqrt{\mathrm{h}_{\mathrm{t}-1}}}
\end{aligned}
$$

To understand whether the conditional variance of the stock returns of the tourism firms in the sample countries were affected by the terrorist attacks, this study followed Kollias et al.'s (2011) equations. Thus, the following equations where defined.

$$
\begin{aligned}
& \mathrm{R}_{\mathrm{t}}=\beta_{0}+\beta_{1} \mathrm{R}_{\mathrm{mt}}+\varepsilon_{\mathrm{t}} \\
& \mathrm{h}_{\mathrm{t}}=\mu+\delta \varepsilon_{\mathrm{t}-1}^{2}+\theta \mathrm{h}_{\mathrm{t}-1}+\psi \mathrm{DM} 1_{\mathrm{t}} \\
& \mathrm{h}_{\mathrm{t}}=\mu+\delta \varepsilon_{\mathrm{t}-1}^{2}+\theta \mathrm{h}_{\mathrm{t}-1}+\lambda \mathrm{DM} 2_{\mathrm{t}+5}
\end{aligned}
$$

Where $R_{t}$ and $R_{m t}$ are tourism companies' stock returns and stock market index returns for each country respectively. The error term, $\varepsilon_{\mathrm{t}}$ is the iid disturbance with zero mean and unit variance. $\mathrm{DM} 1_{\mathrm{t}}$ is a dummy variable which takes the value of 1 on the days at the terrorist incidents occurrences for each country and 0 otherwise which captures the impact of terrorist attacks on the conditional volatility of tourism firms stock returns. An alternative form of this dummy variable is $\mathrm{DM} 2_{\mathrm{t}+5}$ which takes the value of 1 for the event day plus five following days and 0 otherwise. While 
the conditional mean equation (eq.7) is the same, the conditional variance equation is estimated as specified in equation (8) and (9) alternatively for all countries. Therefore, in order to examine whether the conditional variance of the tourism firms' stock returns are affected by tourism terrorist attacks, we estimate equation ( 7 and 8 ) and (7 and 9) separately for each country. Furthermore, the EGARCH model extended by the above mentioned dummy variables have also been estimated for each sampled country.

In the cases when we find evident for asymmetric effects we employ EGARCH $(1,1)$ model and when asymmetric effect found to be statistically insignificant we use symmetric GARCH $(1,1)$ model $^{4}$. Accordingly, EGARCH $(1,1)$ is use test for most of the countries except Germany and Thailand where GARCH $(1,1)$ model found to be appropriate.

We further used Angle and Ng's (1993) Likelihood ratio test statistic (LR) to examine whether the dummy variables in the conditional mean and variance equations had any impact on the conditional mean and volatility. The LR test statistics asymptotically followed the chi-squared distribution with two degrees of freedom and was defined by.

$\mathrm{LR}=-2\left(\mathrm{~L}_{\mathrm{r}}-\mathrm{L}_{\mathrm{u}}\right) \sim \mathrm{x}_{\mathrm{m}}^{2}$

\footnotetext{
${ }^{4}$ The best fit model in both mean and variance equation in the case of Spain found to be following ARMA $(1,0)$ and EGARCH $(1,2)$ respectively. While for UK the best fit model follows ARMA (3, 1) and $\operatorname{EGARCH}(1,2)$.
} 
Where $L_{r}$ the value of log-likelihood is function under the restricted specification (Equation 5 or 6 ); $L_{u}$ is the value of log-likelihood function under the unrestricted specification (Equations 7 and 8). According to the LR test, the null hypothesis states that $\beta_{1}=\psi(\lambda)=0$ in Equations (8) and (9).

Hsieh (1988) and Palm and Vlaar (1997) argue that Generalized Error Distribution (GED), or student's t-distribution, can better capture the excess kurtosis or the heavy tailed conditional distribution of the errors; therefore, the current study used GEDdistribution to estimate both $\operatorname{GARCH}(1,1)$ and $\operatorname{EGARCH}(1,1)$ models. Further robustness testing for the conditional volatility models was conducted by applying the Ljung-Box $\mathcal{Q}_{\mathrm{z}}$-statistics and $\mathcal{Q}_{\mathrm{z}}^{2}$-statistics to test whether the mean and variance equations were well specified. 


\section{Chapter 4}

\section{RESULTS AND DISCUSSION}

\subsection{The Effect of Terror on Tourism Firms' Stock Returns}

Table 6 and Figure 3 present the event study results of the reaction of the tourism index to the terrorist incidents in each sample country. In China, on event day (0) and event day period $(0,+1)$, there are no statistically significant index reactions (i.e. AR and $\operatorname{CAR}(0,+1))$, nor are there any statistically significant cumulative abnormal returns' $(\mathrm{CAR})$ reaction during the longer event window periods $(0,+2),(0,+5)$, and $(0,+10)$. The reason that the terrorist incidents had no impact on the tourism firms in China can be attributed to the regional location of the incident as the attacks took place in the west of the country and very far away from the developed regions of China. Similarly, there are no statistically significant reactions of the tourism index to the only terrorist incident in Germany. The tourism sector in Germany seems not to be affected by terrorism, most probably because of the steady growth of the tourism sector and economy in Germany.

Regarding terrorist incident (1) in France, the tourism index responded negatively by $-1.69 \%$ and $-1.97 \%$ and was statistically significant during the window periods $(0,+1)$ and $(0,+2)$, respectively. Terrorist incident (2) caused a greater negative reaction with a statistically significant impact on the tourism index by $-2.57 \%$ and -2.51 during the window periods $(0,+1)$ and $(0,+2)$, respectively. 
Table 6: The reaction of the tourism index returns to the terrorist incidents using market model of event study

\begin{tabular}{|c|c|c|c|c|c|c|c|}
\hline Country & Event & $\begin{array}{c}\text { Event-day } \\
\text { AR }\end{array}$ & $\operatorname{CAR}(0,+1)$ & $\operatorname{CAR}(0,+2)$ & $\operatorname{CAR}(0,+5)$ & $\mathrm{CAR}(0,+10)$ & $\begin{array}{l}\text { Days to } \\
\text { rebound }\end{array}$ \\
\hline \multirow[t]{3}{*}{ China } & 1 & $\begin{array}{c}0.22 \% \\
(0.15)\end{array}$ & $\begin{array}{c}-0.26 \% \\
(-0.12)\end{array}$ & $\begin{array}{c}0.69 \% \\
(0.27)\end{array}$ & $\begin{array}{c}2.85 \% \\
(0.80)\end{array}$ & $\begin{array}{c}-3.06 \% \\
(-0.63)\end{array}$ & 2 \\
\hline & 2 & $\begin{array}{c}0.10 \% \\
(0.15)\end{array}$ & $\begin{array}{c}-0.27 \% \\
(-0.28)\end{array}$ & $\begin{array}{c}-0.21 \% \\
(-0.18)\end{array}$ & $\begin{array}{c}-1.83 \% \\
(-1.14)\end{array}$ & $\begin{array}{c}-1.08 \% \\
(-0.49)\end{array}$ & 2 \\
\hline & 3 & $\begin{array}{c}-0.26 \% \\
(-0.33) \\
\end{array}$ & $\begin{array}{c}-1.03 \% \\
(-0.94) \\
\end{array}$ & $\begin{array}{c}-0.70 \% \\
(-0.52) \\
\end{array}$ & $\begin{array}{c}-1.12 \% \\
(-0.59) \\
\end{array}$ & $\begin{array}{c}-1.12 \% \\
(-0.43) \\
\end{array}$ & 3 \\
\hline \multirow[t]{2}{*}{ France } & 1 & $\begin{array}{c}0.052 \% \\
(0.08)\end{array}$ & $\begin{array}{c}-\mathbf{1 . 6 9 \%} \% \\
(-1.95)^{*}\end{array}$ & $\begin{array}{c}\mathbf{- 1 . 9 7 \%} \\
(-1.85)^{*}\end{array}$ & $\begin{array}{c}-0.65 \% \\
(-0.43)\end{array}$ & $\begin{array}{c}-0.13 \% \\
(-0.06)\end{array}$ & 8 \\
\hline & 2 & $\begin{array}{c}-0.65 \% \\
(-1.13)\end{array}$ & $\begin{array}{l}-2.57 \% \\
(-3.18)^{* * *}\end{array}$ & $\begin{array}{l}-2.51 \% \\
(-2.54) * *\end{array}$ & $\begin{array}{l}3.31 \% \\
(2.37) * *\end{array}$ & $\begin{array}{l}\mathbf{3 . 5 8 \%} \\
(1.89) \%\end{array}$ & 4 \\
\hline Germany & 1 & $\begin{array}{c}-0.92 \% \\
(-0.51) \\
\end{array}$ & $\begin{array}{c}-1.69 \% \\
(-0.67) \\
\end{array}$ & $\begin{array}{c}-2.47 \% \\
(-0.80)\end{array}$ & $\begin{array}{c}-0.91 \% \\
(-0.20)\end{array}$ & $\begin{array}{c}-2.44 \% \\
(-0.41)\end{array}$ & $>20$ \\
\hline \multirow[t]{2}{*}{ Spain } & 1 & $\begin{array}{c}-1.69 \% \\
(-1.25)\end{array}$ & $\begin{array}{c}-2.52 \% \\
(-1.32)\end{array}$ & $\begin{array}{l}\mathbf{- 5 . 6 5 \%} \% \\
(-2.42) * *\end{array}$ & $\begin{array}{c}-3.16 \% \\
(-0.96)\end{array}$ & $\begin{array}{c}1.28 \% \\
(0.28)\end{array}$ & $>20$ \\
\hline & 2 & $\begin{array}{l}0.07 \% \\
(0.051) \\
\end{array}$ & $\begin{array}{c}-1.19 \% \\
(-0.60) \\
\end{array}$ & $\begin{array}{c}-0.55 \% \\
(-0.22) \\
\end{array}$ & $\begin{array}{c}-1.83 \% \\
(-0.53) \\
\end{array}$ & $\begin{array}{c}-1.28 \% \\
(-0.27) \\
\end{array}$ & 13 \\
\hline Thailand & 1 & $\begin{array}{c}\mathbf{1 . 5 7 \%} \% \\
(1.65)^{*}\end{array}$ & $\begin{array}{l}-\mathbf{5 . 3 5 \%} \\
(-3.99)^{* * *}\end{array}$ & $\begin{array}{l}-4.46 \% \\
(-2.71)^{* * *}\end{array}$ & $\begin{array}{c}-2.74 \% \\
(-1.17) \\
\end{array}$ & $\begin{array}{c}-1.70 \% \\
(-0.53) \\
\end{array}$ & $>20$ \\
\hline Turkey & 1 & $\begin{array}{c}-4.09 \% \\
(-1.20) \\
\end{array}$ & $\begin{array}{c}\mathbf{- 1 0 . 0 8 \%} \\
(-2.10)^{* *}\end{array}$ & $\begin{array}{c}\mathbf{- 1 1 . 0 4 \%} \\
(-1.88)^{*}\end{array}$ & $\begin{array}{c}-12.36 \% \\
(-1.48) \\
\end{array}$ & $\begin{array}{c}-12.16 \% \\
(-1.08)\end{array}$ & 16 \\
\hline \multirow[t]{4}{*}{ UK } & 1 & $\begin{array}{c}0.41 \% \\
(0.59)\end{array}$ & $\begin{array}{c}0.47 \% \\
(0.47)\end{array}$ & $\begin{array}{c}1.82 \% \\
(1.51)\end{array}$ & $\begin{array}{c}2.82 \% \\
(1.66)^{*}\end{array}$ & $\begin{array}{c}-0.39 \% \\
(-0.16)\end{array}$ & 0 \\
\hline & 2 & $\begin{array}{c}1.17 \% \\
(1.46)\end{array}$ & $\begin{array}{c}1.02 \% \\
(0.91)\end{array}$ & $\begin{array}{c}0.28 \% \\
(020)\end{array}$ & $\begin{array}{c}-1.52 \% \\
(-0.78)\end{array}$ & $\begin{array}{l}-\mathbf{1 3 . 3 6 \%} \\
(-5.08)^{* * *}\end{array}$ & 0 \\
\hline & 3 & $\begin{array}{l}-1.23 \% \\
(-2.23) * *\end{array}$ & $\begin{array}{c}-1.25 \% \\
(-1.61)\end{array}$ & $\begin{array}{c}-0.98 \% \\
(-1.02)\end{array}$ & $\begin{array}{c}-1.81 \% \\
(-1.35)\end{array}$ & $\begin{array}{c}-1.78 \% \\
(-0.98)\end{array}$ & $>20$ \\
\hline & 4 & $\begin{array}{c}\mathbf{- 1 . 2 4 \%} \\
(-1.68)^{*}\end{array}$ & $\begin{array}{c}\mathbf{- 1 . 8 3 \%} \% \\
(-1.76)^{*}\end{array}$ & $\begin{array}{c}-1.29 \% \\
(-1.01) \\
\end{array}$ & $\begin{array}{c}-2.65 \% \\
(-1.47) \\
\end{array}$ & $\begin{array}{c}-1.52 \% \\
(-0.62) \\
\end{array}$ & $>20$ \\
\hline \multirow[t]{6}{*}{ U.S. } & 1 & $\begin{array}{c}-0.07 \% \\
(-0.06)\end{array}$ & $\begin{array}{c}0.03 \% \\
(0.02)\end{array}$ & $\begin{array}{c}1.10 \% \\
(0.64)\end{array}$ & $\begin{array}{c}3.95 \% \\
(1.62)\end{array}$ & $\begin{array}{c}2.91 \% \\
(0.88)\end{array}$ & 2 \\
\hline & 2 & $\begin{array}{l}-\mathbf{1 2 . 9 9 \%} \\
(-13.19) * * *\end{array}$ & $\begin{array}{l}\mathbf{- 1 3 . 9 7 \%} \\
(-10.05)^{* * *}\end{array}$ & $\begin{array}{l}-\mathbf{1 4 . 1 3 \%} \\
(-8.30)^{* * *}\end{array}$ & $\begin{array}{l}\mathbf{- 1 5 . 6 5 \%} \\
(-6.50) * * *\end{array}$ & $\begin{array}{l}\mathbf{- 1 4 . 5 6 \%} \\
(-4.46)^{* * * *}\end{array}$ & $>20$ \\
\hline & 3 & $\begin{array}{c}-0.29 \% \\
(-0.49)\end{array}$ & $\begin{array}{c}-0.13 \% \\
(-0.16)\end{array}$ & $\begin{array}{c}0.12 \% \\
(0.11)\end{array}$ & $\begin{array}{c}-2.25 \% \\
(-1.59)\end{array}$ & $\begin{array}{l}-4.19 \% \\
(-2.19)^{* *}\end{array}$ & 0 \\
\hline & 4 & $\begin{array}{c}0.39 \% \\
(0.68050)\end{array}$ & $\begin{array}{l}0.71 \% \\
(0.884)\end{array}$ & $\begin{array}{l}0.52 \% \\
(0.532)\end{array}$ & $\begin{array}{l}0.27 \% \\
(0.196)\end{array}$ & $\begin{array}{l}0.22 \% \\
(0.115)\end{array}$ & 0 \\
\hline & 5 & $\begin{array}{c}-0.18 \% \\
(-0.29)\end{array}$ & $\begin{array}{c}-0.80 \% \\
(-0.92)\end{array}$ & $\begin{array}{c}-0.44 \% \\
(-0.41)\end{array}$ & $\begin{array}{c}-0.27 \% \\
(-0.17)\end{array}$ & $\begin{array}{c}\mathbf{- 3 . 8 5 \%} \\
(-1.90)^{*}\end{array}$ & 20 \\
\hline & 6 & $\begin{array}{c}-0.23 \% \\
(-0.52)\end{array}$ & $\begin{array}{c}0.49 \% \\
(0.79)\end{array}$ & $\begin{array}{c}0.69 \% \\
(0.92)\end{array}$ & $\begin{array}{c}1.48 \% \\
(1.38)\end{array}$ & $\begin{array}{c}2.08 \% \\
(1.44)\end{array}$ & 0 \\
\hline
\end{tabular}

Notes: The values in the parentheses are t-statistics. *,**, and $* * *$ represent $10 \%$, $5 \%$, and $1 \%$ levels of significance, respectively.

However, during event periods $(0,+5)$ and $(0,+10)$, the reaction returns were positive and statistically significant by $3.31 \%$ and $3.58 \%$, respectively. These results illustrate 
that the tourism industry was affected temporarily by the terrorist incidents, implying that the performance of the French tourism industry was mainly driven by other fundamental news.

In Spain, for terrorist incident (1) the Madrid train bombings by al-Qaeda in 2004, there is a statistically significant negative tourism index reaction of $-5.65 \%$ for event window $(0,+2)$. In the case of Barcelona terrorist incident (2), the tourism index shows no statistically significant reactions. The temporary negative impact of Madrid incident (1) and the minimal impact of Barcelona incident (2) imply the reliance of tourism companies on the steady growth of the tourism sector as well as the investors' confidence in the development of the tourism sector.

In Thailand, on event day (0), there is a positive and statistically significant tourism index reaction of $1.57 \%$. However, this reaction cannot be attributed to the terrorist incident, as the attack happened after the close of stock trading. Nonetheless, the tourism index reacted negatively in the subsequent trading day, and the CAR for event day period $(0,+1)$ is a statistically significant value of $-5.35 \%$. For event window $(0,+2)$, the CAR is $-4.46 \%$ and is statistically significant.

In Turkey, the abnormal returns of the tourism index are considerably high on event day (0), albeit statistically insignificant. However, the CARs for event day periods $(0,+1)$ and $(0,+2)$ have high statistically significant values of $-10.08 \%$ and $-11.04 \%$, respectively. Comparatively, the Turkish tourism index reaction has the third highest negative values after the U.S. tourism index reaction to the $9 / 11$ terrorist attacks and the two bombings in Northern Ireland (i.e. UK incident (2)). The United Kingdom 
has had several terrorist attacks. As Table 5 shows, the return impact of terrorist incident (1) on the tourism index is positive and statistically significant for event period $(0,+5)$. This finding is contrary to the anticipated negative reaction. For terrorist incidents (2), (3), and (4), the UK tourism sector index reacted negatively and, particularly for incident (2), there is a cumulative negative market reaction of $-13.36 \%(\operatorname{CAR}(0,+10)) .^{5}$

Among the six terrorist incidents in different U.S. states over several years, the results show that the U.S. tourism index has been highly reactive only to terrorist incident (2) (i.e. 9/11). The reaction is statistically significant and reaches a cumulative abnormal return level of $-14.56 \%(\mathrm{CAR}(0,+10))$, which is the highest one among all the sample incidents. Similarly, this result is in line with Goel et al.'s (2017) finding that, among the sixteen terrorist incidents in the United States, the 9/11 attacks provoked statistically significant reactions only in the stock and bond market returns. In reaction to the tourism index of terrorist incidents (3) and (5), the cumulative abnormal returns during period $(\operatorname{CAR}(0,+10))$ was $-4.19 \%$ and $+3.85 \%$, respectively. These responses can be ascribed to the fact that it relatively took a long time for the investors to assess the future costs of the incident before revealing their reactions.

The last column of Table 6 shows the number of days it takes the tourism index to rebound to the pre-incident level. The tourism index in China recovered very quickly (within 2-3 days). Similarly, the tourism index of incidents (1) and (2) in France recovered swiftly (8-4 days, respectively). The tourism index in Turkey was severely

\footnotetext{
${ }^{5}$ The high negative reaction during period $(\operatorname{CAR}(0,+10))$ is attributed to the other events rather than terrorist incident (2), as the pre-incident period abnormal return (CAR(-10,-1)) was $-9.20 \%$ and was statistically significant at $1 \%$.
} 
affected by the terrorist incidents, and the index level recovered in 16 days. The impact of the terrorist attacks on the tourism indices in Germany, Spain, Thailand, the United Kingdom, and the United States was particularly long-lasting and it took more than 20 days to rebound.
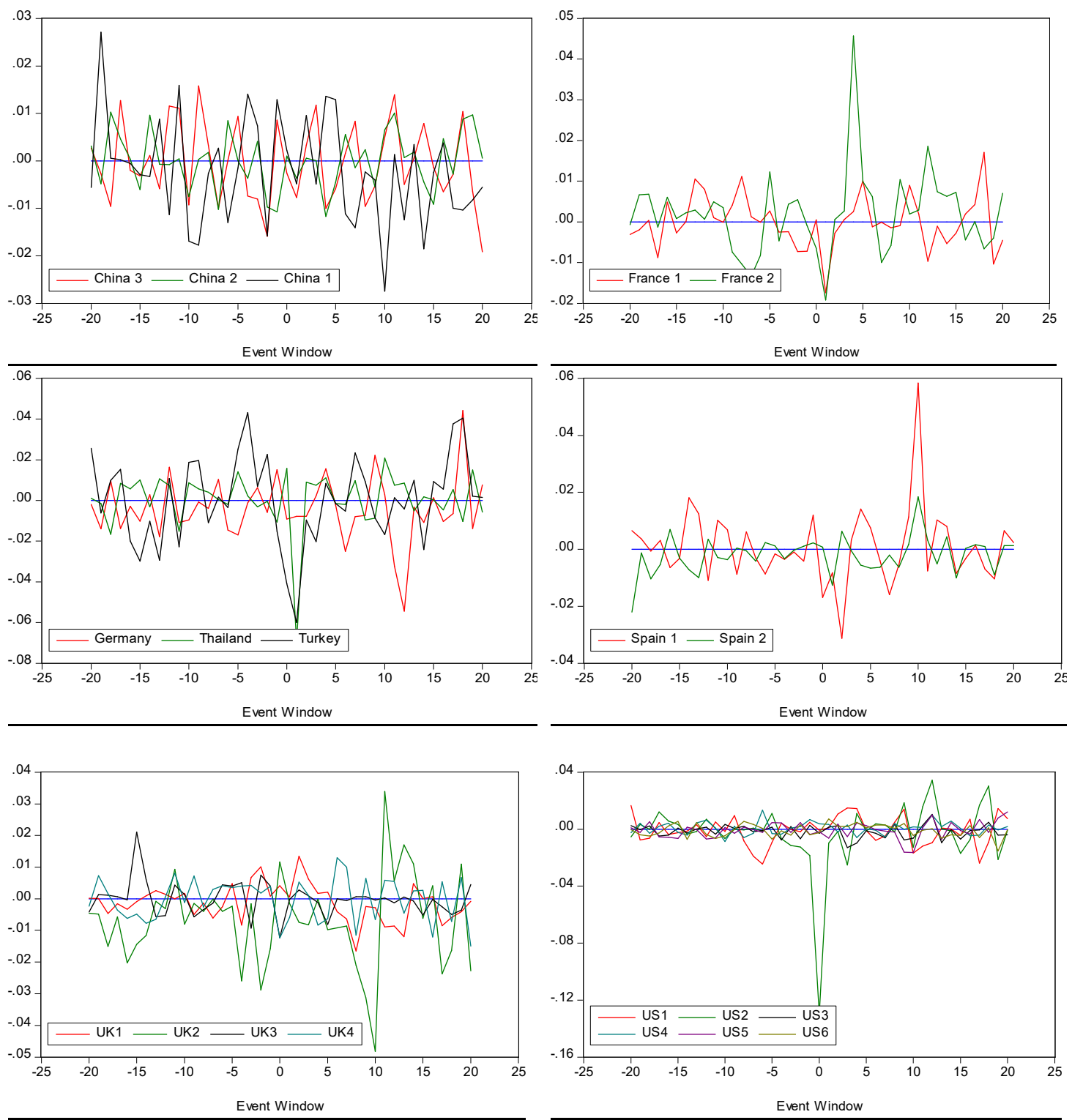

Figure 3: The abnormal returns over the event window 
Table 7: The reaction of tourism index returns to the terrorist incidents using mean adjusted model of event study

\begin{tabular}{|c|c|c|c|c|c|c|}
\hline Country & Event & Event-Day AR & $\operatorname{CAR}(0,+1)$ & $\operatorname{CAR}(0,+2)$ & $\operatorname{CAR}(0,+5)$ & $\operatorname{CAR}(0,+10)$ \\
\hline China & 2 & $\begin{array}{c}1.35 \% \\
0.93 \\
-0.46 \% \\
-0.70 \\
0.84 \% \\
1.08 \\
\end{array}$ & $\begin{array}{c}-0.53 \% \\
-0.12 \\
-1.04 \% \\
-0.56 \\
-0.09 \% \\
-0.04 \\
\end{array}$ & $\begin{array}{c}-0.05 \% \\
-0.02 \\
0.39 \% \\
0.35 \\
-0.73 \% \\
-0.55 \\
\end{array}$ & $\begin{array}{c}1.63 \% \\
0.46 \\
-0.87 \% \\
-0.55 \\
-\mathbf{4 . 0 1 \%} \\
-2.12 * * \\
\end{array}$ & $\begin{array}{c}1.40 \% \\
0.29 \\
-0.06 \% \\
-0.03 \\
-2.37 \% \\
-0.92 \\
\end{array}$ \\
\hline France & $\begin{array}{l}1 \\
2\end{array}$ & $\begin{array}{c}0.12 \% \\
0.19 \\
\mathbf{- 1 . 4 3 \%} \\
-2.50 * *\end{array}$ & $\begin{array}{l}-\mathbf{2 . 8 6 \%} \\
-2.18 * * \\
-\mathbf{3 . 4 8 \%} \\
-2.13^{* *}\end{array}$ & $\begin{array}{c}\mathbf{- 3 . 7 0 \%} \\
-3.49 * * * \\
\mathbf{- 1 . 5 3 \%} \\
-2.55 * * * \\
\end{array}$ & $\begin{array}{c}\mathbf{- 3 . 1 3 \%} \\
-2.08 * * \\
3.70 \% \\
1.65 \\
\end{array}$ & $\begin{array}{c}-2.21 \% \\
-1.09 \\
3.90 \% \\
1.06 \\
\end{array}$ \\
\hline Germany & 1 & $\begin{array}{c}-1.42 \% \\
-0.80 \\
\end{array}$ & $\begin{array}{c}-2.55 \% \\
-0.79 \\
\end{array}$ & $\begin{array}{c}-4.00 \% \\
-1.30 \\
\end{array}$ & $\begin{array}{c}-4.55 \% \\
-1.05 \\
\end{array}$ & $\begin{array}{c}-8.60 \% \\
-1.46 \\
\end{array}$ \\
\hline Spain & 1 & $\begin{array}{c}\mathbf{- 2 . 7 8 \%} \\
-2.07 * * \\
-0.42 \% \\
-0.30 \\
\end{array}$ & $\begin{array}{c}-\mathbf{4 . 2 0 \%} \\
-2.10 * * \\
-1.88 \% \\
-0.87 \\
\end{array}$ & $\begin{array}{c}\mathbf{- 9 . 2 5 \%} \\
-3.97 * * * \\
-1.21 \% \\
-0.50 \\
\end{array}$ & $\begin{array}{c}-\mathbf{6 . 6 0 \%} \\
-2.00 * * \\
-1.85 \% \\
-0.54 \\
\end{array}$ & $\begin{array}{c}-2.48 \% \\
-0.56 \\
-0.62 \% \\
-0.13 \\
\end{array}$ \\
\hline Thailand & 1 & $\begin{array}{c}1.35 \% \\
1.42 \\
\end{array}$ & $\begin{array}{c}-7.69 \% \\
-4.76^{* * *} \\
\end{array}$ & $\begin{array}{c}-\mathbf{- 6 . 3 0 \%} \\
-3.83 * * * \\
\end{array}$ & $\begin{array}{c}\mathbf{- 9 . 2 0 \%} \\
-3.96 * * * \\
\end{array}$ & $\begin{array}{c}-2.44 \% \\
-0.78 \\
\end{array}$ \\
\hline Turkey & 1 & $\begin{array}{c}\mathbf{- 1 0 . 8 \%} \\
-3.18 * * * \\
\end{array}$ & $\begin{array}{c}-9.22 \% \\
-1.63 \\
\end{array}$ & $\begin{array}{c}-9.42 \% \\
-1.60 \\
\end{array}$ & $\begin{array}{c}-10.80 \% \\
-1.30 \\
\end{array}$ & $\begin{array}{c}-10.64 \% \\
-0.95 \\
\end{array}$ \\
\hline UK & $\begin{array}{l}1 \\
2 \\
3 \\
4\end{array}$ & $\begin{array}{c}0.63 \% \\
0.92 \\
1.7 \% \\
2.128 * * \\
\mathbf{- 2 . 4 8 \%} \\
-4.52 * * * \\
\mathbf{- 1 . 6 6 \%} \\
-2.25 \\
\end{array}$ & $\begin{array}{c}0.60 \% \\
0.49 \\
\mathbf{3 . 2 3 \%} \\
2.59 * * * \\
-1.45 \% \\
-1.45 \\
-2.39 \% \\
-1.61 \\
\end{array}$ & $\begin{array}{c}1.91 \% \\
1.59 \\
\mathbf{3 . 2 3 \%} \\
2.36 * * \\
-1.14 \% \\
-1.20 \\
\mathbf{- 2 . 5 9 \%} \\
-2.04 * * \\
\end{array}$ & $\begin{array}{c}1.99 \% \\
1.17 \\
1.83 \% \\
0.95 \\
-2.08 \% \\
-1.55 \\
\mathbf{- 3 . 9 0 \%} \\
-2.17 * * \\
\end{array}$ & $\begin{array}{c}-0.70 \% \\
-0.30 \\
\mathbf{- 1 0 . 4 8 \%} \\
-3.99 * * * \\
-3.28 \% \\
-1.81 \\
-3.26 \% \\
-1.34 \\
\end{array}$ \\
\hline US & 3 & $\begin{array}{c}-0.44 \% \\
-0.45 \\
\mathbf{- 1 5 . 6 \%} \\
-15.8 * * * \\
1.13 \% \\
1.65 \\
-0.07 \% \\
-0.12 \\
-0.83 \% \\
-1.36 \\
0.29 \% \\
0.67\end{array}$ & $\begin{array}{c}-0.60 \% \\
-0.33 \\
\mathbf{- 1 6 . 8 6 \%} \\
-9.63 * * * \\
1.61 \% \\
1.12 \\
1.39 \% \\
0.98 \\
-1.46 \% \\
-0.83 \\
1.36 \% \\
1.46\end{array}$ & $\begin{array}{c}0.95 \% \\
0.55 \\
\mathbf{- 1 7 . 8 6 \%} \\
-10.49 * * * \\
\mathbf{2 . 0 2 \%} \\
2.02 * * \\
2.31 \% \\
1.35 \\
-1.13 \% \\
-1.06 \\
\mathbf{1 . 8 2 \%} \\
2.43 * *\end{array}$ & $\begin{array}{c}5.24 \% \\
1.16 \\
\mathbf{- 1 9 . 9 3 \%} \\
-8.28 * * * \\
0.59 \% \\
0.42 \\
0.78 \% \\
0.57 \\
0.13 \% \\
0.09 \\
\mathbf{3 . 2 6 \%} \\
3.08 * * * \\
\end{array}$ & $\begin{array}{c}5.57 \% \\
1.50 \\
\mathbf{- 1 6 . 9 4 \%} \\
-5.20 * * * \\
-0.84 \% \\
-0.44 \\
0.26 \% \\
0.14 \\
\mathbf{- 6 . 6 2 \%} \\
-3.27 * * * \\
\mathbf{5 . 0 1 \%} \\
3.49 * * * \\
\end{array}$ \\
\hline
\end{tabular}

Notes: The values in parentheses are t-statistics. $*$, ** \& *** represent $10 \%, 5 \% \&$ $1 \%$ level of significance respectively. 
Table 7 exhibits the reaction of tourism firms' stock returns to the terrorist incidents using mean adjusted model of the event study. With a few exceptions of statistically significance level of ARs, the obtained results are very similar to those in Table 5 using market model of the event study.

Estimating the abnormal returns by using the mean return model, the abnormal returns on event day (0) for France's terrorist incident (2) is $-1.46 \%$ and is statistically significant at $5 \%$ level. The abnormal returns on event day (0) for Madrid terrorist incident (1) is $-2.67 \%$ and is statistically significant at $5 \%$ level, as well as, the abnormal returns on event day (0) for Turkey is $-10.46 \%$ and is statistically significant at $1 \%$. Lastly, Overall findings of mean adjusted return model support the findings of market model and the evidence of inverse influences of terrorist attack shocks on the tourism firms' stock returns.

The observed differences of tourism indices and speed of tourism indices in rebound across the sample countries can be attributed to the investors' views about the implications of the terrorist attacks. We postulate that, after a terrorist incident, investors may be influenced by the nature of the attack and whether it heralds further attacks in the future; they may also be influenced by the strength of the tourism industry and whether the tourism firms' performance is driven by the fundamentals (i.e. tourism sector development and economic growth) or is very sensitive to shocks.

According to Table 8, both average abnormal returns (AARs) and cumulative average abnormal returns (CAARs) are negative and statistically significant for all the incidents. However, among the CARs in Table 5, there are two extreme values 
that belong to an incident in Turkey and 9/11 in the United States. The AARs and CAARs were tested again by excluding these two incidents, and the results are shown in Table 7. The magnitude of AARs on the event day decreases sharply and becomes statistically insignificant. However, event period $(0,+1)$ and the post-event periods remain negative and statistically significant. Overall, the non-parametric Gsign test results support the parametric t-statistic results in Table 7. Excluding the two outliers, the G-sign tests are not statistically significant in AARs and CAAR $(0,+5)$. The percentage of the number of negative abnormal returns is between $61 \%$ and $75 \%$ in the results, supporting the negative reaction to the terrorist incidents. The CAARs are exhibited graphically in Figure 4. The figure is to further enhance the abovementioned findings, as it illustrates that tourism indices continue to register negative CARs after day (0) through-out the event window until day $(+20)$.

Table 8: AARs and CAARs and their corresponding Generalized Sign test results

\begin{tabular}{|c|c|c|c|c|c|c|}
\hline & $\begin{array}{l}\text { All } \\
\text { sample } \\
\text { incident } \\
\text { s }\end{array}$ & $\begin{array}{l}\text { G-Sign test } \\
\%<0\end{array}$ & $\begin{array}{l}\text { Excluding } \\
1^{\text {st }} \text { outlier }\end{array}$ & $\begin{array}{l}\text { G-Sign } \\
\text { test } \%< \\
0\end{array}$ & $\begin{array}{l}\text { Excluding } 1^{\text {st }} \\
\& 2^{\text {nd }} \\
\text { outliers }\end{array}$ & $\begin{array}{l}\text { G-Sign test } \\
\%<0\end{array}$ \\
\hline AAR & $\begin{array}{l}-\mathbf{0 . 9 9 \%} \\
(-3.54)^{* * *}\end{array}$ & $\begin{array}{l}60 \% \\
{[0.82]}\end{array}$ & $\begin{array}{l}-0.36 \% \\
(-1.25)\end{array}$ & $\begin{array}{l}57.89 \% \\
{[0.62]}\end{array}$ & $\begin{array}{l}-0.15 \% \\
(-0.72)\end{array}$ & $\begin{array}{l}55.56 \% \\
{[0.45]}\end{array}$ \\
\hline $\operatorname{CAAR}(0,+1)$ & $\begin{array}{l}-2.10 \% \\
(-5.29) * * *\end{array}$ & $\begin{array}{l}\mathbf{7 5 \%} \\
{[9.54]^{* * *}}\end{array}$ & $\begin{array}{l}-1.47 \% \\
(-3.62) * * *\end{array}$ & $\begin{array}{c}73.68 \% \\
{[8.61]^{* * *}}\end{array}$ & $\begin{array}{l}\mathbf{- 0 . 9 9 \%} \\
(-3.31)^{* * *}\end{array}$ & $\begin{array}{l}72 \% \\
{[7.90]^{* * *}}\end{array}$ \\
\hline $\operatorname{CAAR}(0,+2)$ & $\begin{array}{l}-2.06 \% \\
(-4.24) * * *\end{array}$ & $\begin{array}{l}\mathbf{6 5 \%} \\
{[5.60]^{* * *}}\end{array}$ & $\begin{array}{l}-\mathbf{1 . 4 2 \%} \% \\
(-2.86)^{* *}\end{array}$ & $\begin{array}{l}\mathbf{6 3 . 1 6 \%} \\
{[4.66]^{* * *}}\end{array}$ & $\begin{array}{l}-\mathbf{0 . 8 9} \% \\
(-2.42)^{* *}\end{array}$ & $\begin{array}{l}\mathbf{6 1 \%} \\
{[3.91]^{* * *}}\end{array}$ \\
\hline $\operatorname{CAAR}(0,+5)$ & $\begin{array}{l}-\mathbf{1 . 7 0} \% \\
(-2.48)^{* *}\end{array}$ & $\begin{array}{l}\mathbf{7 0 \%} \\
{[7.57]^{* * *}}\end{array}$ & $\begin{array}{l}\mathbf{- 0 . 9 7 \%} \\
(-1.37)\end{array}$ & $\begin{array}{l}\mathbf{6 8 . 4 2 \%} \% \\
{[6.63]^{* * *}}\end{array}$ & $\begin{array}{l}-0.34 \% \\
(-0.64)\end{array}$ & $\begin{array}{l}\mathbf{6 7 \%} \\
{[5.90]^{* * *}}\end{array}$ \\
\hline $\operatorname{CAAR}(0,+10)$ & $\begin{array}{l}\mathbf{- 2 . 6 3 \%} \\
(-2.83) * *\end{array}$ & $\begin{array}{l}\mathbf{7 5 \%} \\
{[9.54]^{* * *}}\end{array}$ & $\begin{array}{l}\mathbf{- 2 . 0 0 \%} \\
(-2.10)^{*}\end{array}$ & $\begin{array}{l}\mathbf{7 3 . 6 8 \%} \\
{[8.61]^{* * * *}}\end{array}$ & $\begin{array}{l}\mathbf{- 1 . 4 4 \%} \\
(-2.04)^{*}\end{array}$ & $\begin{array}{l}\mathbf{7 2 \%} \\
{[7.90]^{* * *}}\end{array}$ \\
\hline
\end{tabular}

Notes: The values in the parentheses and brackets [-] are t-statistics and Generalized $Z$ statistics, respectively. The $1^{\text {st }}$ and $2^{\text {nd }}$ outliers are the $9 / 11$ terrorist attacks in the United States and the 2003 terrorist incidents in Turkey, respectively. *, **, and *** represent $10 \%, 5 \%$, and $1 \%$ levels of significance, respectively. 
Panel A: Including All the Sample

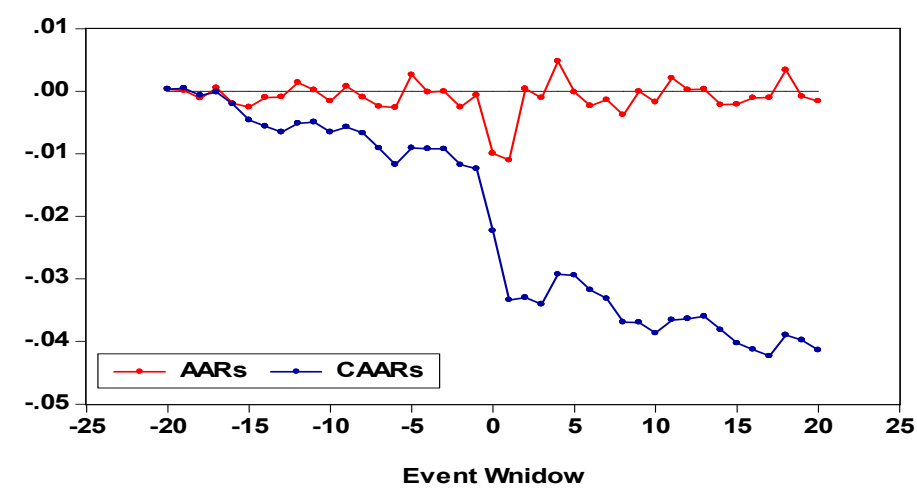

Panel B: Excluding the First Outlier

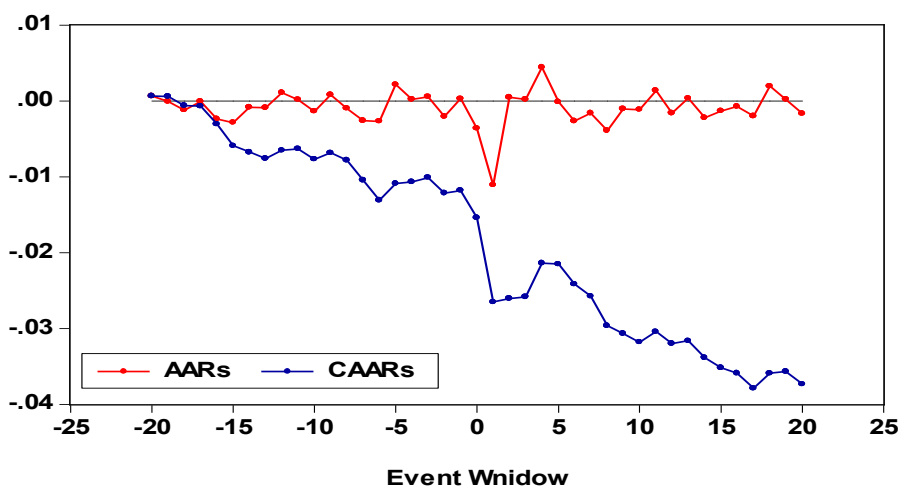

Panel C: Excluding the First and Second Outliers

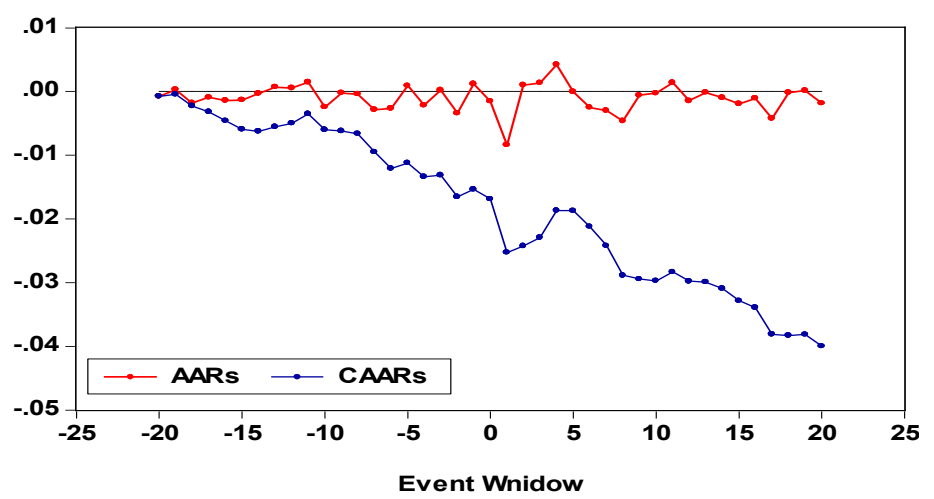

Figure 4: Average abnormal returns and cumulative average abnormal returns over the event window 


\subsection{The Effect of Terror on Tourism Firms' Stock Returns Volatility}

In Table 9, both GARCH and EGARCH estimations are presented ${ }^{6}$. Based on the Likelihood ratio test statistic (LR), when there was evidence of an asymmetric effect, the EGARCH $(1,1)$ model was estimated instead of the GARCH $(1,1)$ model. The coefficient of dummy variables terrorist incidents $(\psi)$ is statistically significant at $1 \%$ level of significance in the cases of France, Thailand, and the United States, implying that the terrorist attacks impact on the volatility of the tourism firms' stock returns in those countries; however, it is insignificant for the rest of the sample countries. Moreover, $\lambda$ attempts to capture the extended effect of terrorist incidents on the volatility of tourism indices over a week after the attacks. It is statistically significant only for Thailand and the United States. The leverage effect is observed in the cases of China and Turkey, since the asymmetric coefficient $(\gamma)$ is negative and statistically significant, while the asymmetry coefficient is positive and statistically significant with respect to the tourism firms in France, Spain, the United Kingdom, and the United States; this implies that good news injects more volatility into the stock prices than bad news does with the same magnitude. The $(\delta)$ parameter is highly significant in all the estimated models, providing evidence of a clustering effect (i.e., large shocks followed by large volatility in either sign.) GARCH parameter $(\theta)$ is very close to unity for the majority of the countries, which is, on average, approximately 0.985 except for Germany; this indicates that $98.5 \%$ of volatility in the past period is carried to the current and next periods, and the conditional variance moves very slowly toward the long-run variance. In other words, the impact of the shocks is long-lasting.

\footnotetext{
${ }^{6}$ Estimating Equations (3) and (4) and Equations (3) and (5) yield the same conclusion for all the variables except $\psi$ and $\lambda$. Therefore, the reported parameters in Table 5 belong to the estimated results of Equations (3) and (4) except $\lambda$, which is from Equations (3) and (5).
} 
Moreover, the estimated GED parameter is highly statistically significant in all the models. The Box-Pierce $\mathcal{Q}_{\mathrm{z}}$-statistics show that there is no significant autocorrelation of the standardized residuals at lag (12), implying that the mean equation is well specified. The $\mathcal{Q}_{\mathrm{z}}^{2}$-statistics test also suggests that the squared standardized residuals are not significant at lag (12), indicating that all the ARCH effects have been captured by the proposed model of this study. 
Table 9: Conditional volatility and the impact of terrorist incidents on the indices

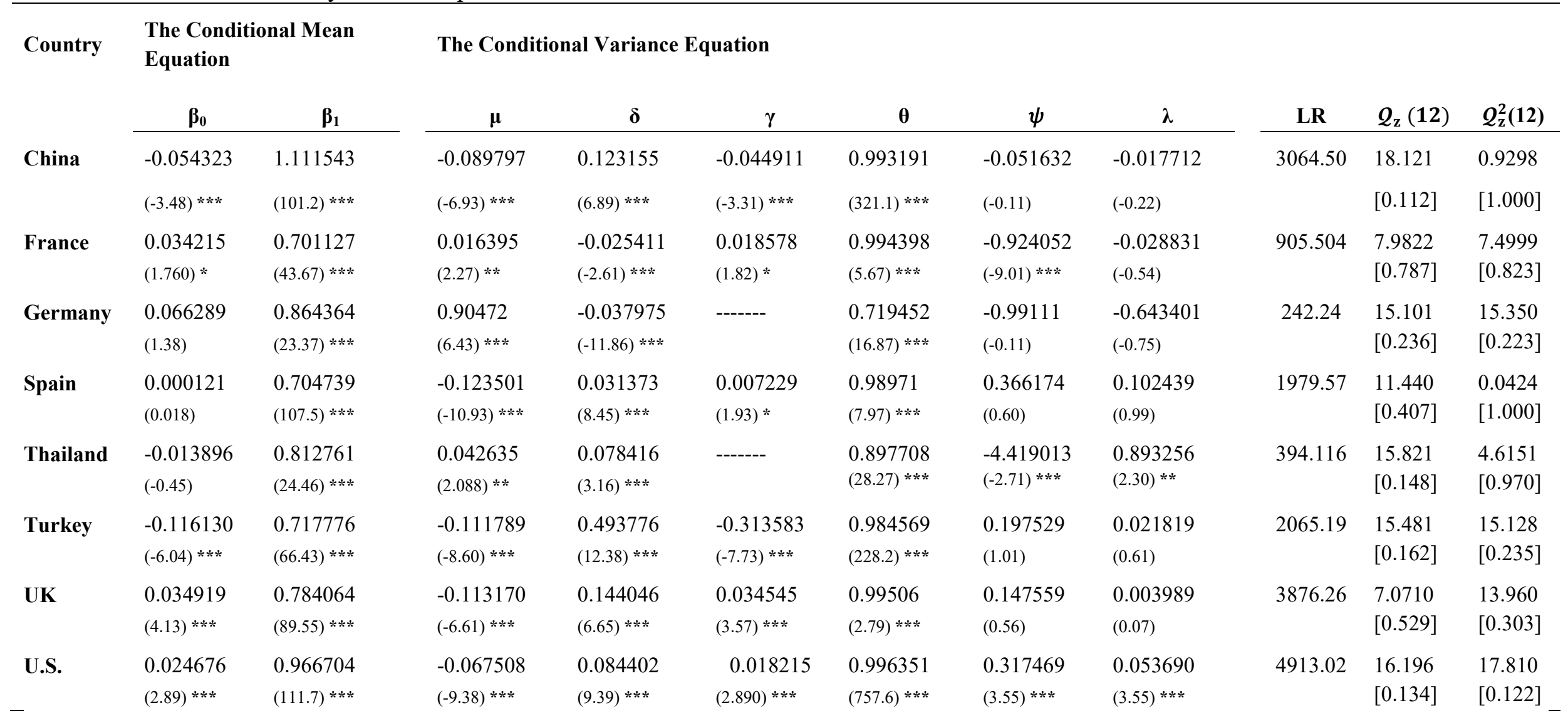

Note: The returns of the indices are calculated as $\ln \left(\mathrm{R}_{\mathrm{t} 0} / \mathrm{R}_{\mathrm{t}-1}\right) * 100$. The chi-square critical value for 2 degrees of freedom is $9.21,5.991$, and 4.605 for $1 \%, 5 \%$, and $10 \%$ levels of significance, respectively. The values between the parentheses are Z-statistic. *, **, and $* * *$ represent $10 \%$, $5 \%$, and $1 \%$ levels of significance, respectively. The values between [ ] are prob. values of Box-Pierce statistics. 


\section{Chapter 5}

\section{CONCLUSION}

This study has examined the effects of terrorist attacks on the stock performance and volatility of tourism, travel, and leisure industries in the major tourist destination countries. The ten tourist destination countries with the highest tourist arrivals or tourism receipt as ranked by the World Tourism Organization in 2017, namely China, France, Germany, Spain, Thailand, Turkey, United Kingdom, and the United States were selected for the purpose of this study. In particular, this study adopted both event study and volatility analysis to examine the impact of terrorist incidents on tourism firms' stock returns and volatility. This study makes two distinct contributions to the relevant literature. First, unlike previous studies, this study focused on the effects of terrorism on tourism, travel, and leisure companies in the selected countries. Second, this investigation was carried out using event study.

According to the obtained results, the country-specific illustrated the significant effects of the terrorist attacks on tourism firms' performance in France, Spain, Thailand, Turkey, the United Kingdom, and the United States. The significant effects of the terrorist attacks on tourism firms' stock volatility were only obtained for France, Thailand, and the United States. Further, although there have been serious terrorist attacks in China and Germany, no significant effects on the tourism, travel, and leisure industries were obtained. This is not very surprising, mainly because both 
economies are strong and minimally vulnerable to the external shocks; to this, China's vast geographic extent may be added.

Investigating the number of days it takes the tourism indices to rebound to the preincident level, it is observed that tourism index in China and France recovered very quickly, while, the index affected more in Turkey. However, the impact of the terrorist attacks on the tourism indices in Germany, Spain, Thailand, the United Kingdom, and the United States was particularly long-lasting.

The major limitation of this research was the exclusion of Italy, because there had been no severe terrorist attacks in that country and the Russian Federation, because data on the tourism index were unavailable for this country. Second, the overall panel event study analysis illustrated a very high level of adverse effects of terrorist attacks on firms' performance in tourism, travel, and leisure industry. Thus, there is strong evidence that terrorist attacks have impacted significantly on the aggregate stock performance of tourism, travel, and leisure industries in the major tourist destination countries. The findings of this study are consistent with the semi-strong form of the Efficient Market Hypothesis, while the results are expected to be of high importance for the financial managers, investors, and portfolio managers, as far as their financial planning, speculations, hedging, and portfolio strategies are concerned. As a further research, we recommend similar studies to be undertaken on the subject of this paper using qualitative methods (i.e. structured interviews) for comparison purposes. 


\section{REFERENCES}

Abadie, A., \& Gardeazabal, J. (2008). Terrorism and the world economy. European Economic Review, 52(1), 1-27.

Agnew, R. (2010). A general strain theory of terrorism. Theoretical Criminology, 14(2), 131-153.

Ahlfeldt, G. M., Franke, B., \& Maennig, W. (2015). Terrorism and international tourism: The case of Germany. Jahrbücher für Nationalökonomie und Statistik, 235(1), 3-21.

Aksoy, M., \& Demiralay, S. (2017). The effects of terrorism on Turkish financial markets. Defence and Peace Economics, 1-23.

AlBattat, A. R., \& Mat Som, A. P. (2013). Emergency preparedness for disasters and crises in the hotel industry. Sage Open. doi:10.1177/2158244013505604.

Apergis, E., \& Apergis, N. (2016). The 11/13 Paris terrorist attacks and stock prices: The case of the international defense industry. Finance Research Letters, 17, 186-192.

Araña, J. E., \& León, C. J. (2008). The impact of terrorism on tourism demand. Annals of Tourism Research, 35(2), 299-315. 
Arin, K. P., Ciferri, D., \& Spagnolo, N. (2008). The price of terror: The effects of terrorism on stock market returns and volatility. Economics Letters, 101(3), $164-167$.

Balcilar, M., Gupta, R., Pierdzioch, C., \& Wohar, M. E. (2018). Terror attacks and stock-market fluctuations: Evidence based on a nonparametric causality-inquantiles test for the G7 countries. The European Journal of Finance, 24(4), $333-346$.

Bassil, C., Saleh, A. S., \& Anwar, S. (2019). Terrorism and tourism demand: A case study of Lebanon, Turkey and Israel. Current Issues in Tourism, 22(1), 5070.

Bollerslev, T. (1986). Generalized autoregressive conditional heteroskedasticity. Journal of Econometrics, 31(3), 307-327.

Brida, J. G., Cortes-Jimenez, I., \& Pulina, M. (2016). Has the tourism-led growth hypothesis been validated? A literature review. Current Issues in Tourism, 19(5), 394-430.

Brounen, D., \& Derwall, J. (2010). The impact of terrorist attacks on international stock markets. European Financial Management, 16(4), 585-598.

Brown, S. J., \& Warner, J. B. (1985). Using daily stock returns: The case of event studies. Journal of Financial Economics, 14(1), 3-31. 
Chen, A. H., \& Siems, T. F. (2004). The effects of terrorism on global capital markets. European Journal of Political Economy, 20(2), 349-366.

Chen, M. H. (2011). The response of hotel performance to international tourism development and crisis events. International Journal of Hospitality Management, 30(1), 200-212.

Chesney, M., Reshetar, G., \& Karaman, M. (2011). The impact of terrorism on financial markets: An empirical study. Journal of Banking \& Finance, 35(2), 253-267.

Cowan, A. R. (1992). Nonparametric event study tests. Review of Quantitative Finance and Accounting, 2(4), 343-358.

Cró, S., \& Martins, A. M. (2017). Structural breaks in international tourism demand: Are they caused by crises or disasters? Tourism Management, 63, 3-9.

De Vita, G., \& Kyaw, K. S. (2016). Tourism development and growth. Annals of Tourism Research, 60(9), 23-26.

Drakos, K. (2004). Terrorism-induced structural shifts in financial risk: Airline stocks in the aftermath of the September $11^{\text {th }}$ terror attacks. European Journal of Political Economy, 20(2), 435-446. 
Drakos, K. (2004). Terrorism-induced structural shifts in financial risk: airline stocks in the aftermath of the September 11th terror attacks. European Journal of Political Economy, 20(2), 435-446.

Enders, W., \& Sandler, T. (1996). Terrorism and foreign direct investment in Spain and Greece. Kyklos, 49(3), 331-352.

Enders, W., Sachsida, A., \& Sandler, T. (2006). The impact of transnational terrorism on US foreign direct investment. Political Research Quarterly, 59(4), 517-531.

Engle, R. F. (1982). Autoregressive conditional heteroscedasticity with estimates of the variance of United Kingdom inflation. Econometrica: Journal of the Econometric Society, 50(4), 987-1007.

Engle, R. F., \& Ng, V. K. (1993). Measuring and testing the impact of news on volatility. The Journal of Finance, 48(5), 1749-1778.

Essaddam, N., \& Karagianis, J. M. (2014). Terrorism, country attributes, and the volatility of stock returns. Research in International Business and Finance, 31, 87-100.

Fama, E. F., Fisher, L., Jensen, M. C., \& Roll, R. (1969). The adjustment of stock prices to new information. International economic review, 10(1), 1-21. 
Feridun, M. (2011). Impact of terrorism on tourism in Turkey: Empirical evidence from Turkey. Applied Economics, 43(24), 3349-3354.

Goel, S., Cagle, S., \& Shawky, H. (2017). How vulnerable are international financial markets to terrorism? An empirical study based on terrorist incidents worldwide. Journal of Financial Stability, 33, 120-132.

Herwartz, H. (2017). Stock return prediction under GARCH: An empirical assessment. International Journal of Forecasting, 33(3), 569-580.

Hsieh, D. A. (1988). The statistical properties of daily foreign exchange rates: 1974 1983. Journal of International Economics, 24(1-2), 129-145.

Johnston's Archive. (2018, March 30). Retrieved from http://www.johnstonsarchive.net/terrorism/wrjp255b.html

Katircioglu, S. T. (2009a). Testing the tourism-led growth hypothesis: The case of Malta. Acta Oeconomica, 59(3), 331-343.

Katircioglu, S. T. (2009b). Revisiting the tourism-led-growth hypothesis for Turkey using the bounds test and Johansen approach for cointegration. Tourism Management, 30(1), 17-20.

Katircioğlu, S. T. (2010). International tourism, higher education and economic growth: The case of North Cyprus. The World Economy, 33(12), 1955-1972. 
Katircioğlu, S. T. (2011). Tourism and growth in Singapore: New extension from bounds test to level relationships and conditional Granger causality tests. The Singapore Economic Review, 56(03), 441-453.

Kolaric, S., \& Schiereck, D. (2016). Are stock markets efficient in the face of fear? Evidence from the terrorist attacks in Paris and Brussels. Finance Research Letters, 18, 306-310.

Kollias, C., Papadamou, S., \& Stagiannis, A. (2011). Terrorism and capital markets: The effects of the Madrid and London bomb attacks. International Review of Economics \& Finance, 20(4), 532-541.

Kosová, R., \& Enz, C. A. (2012). The terrorist attacks of 9/11 and the financial crisis of 2008: The impact of external shocks on US hotel performance. Cornell Hospitality Quarterly, 53(4), 308-325.

Liu, A., \& Pratt, S. (2017). Tourism's vulnerability and resilience to terrorism. Tourism Management, 60, 404-417.

Llussá, F., \& Tavares, J. (2011). Which terror at which cost? On the economic consequences of terrorist attacks. Economics Letters, 110(1), 52-55.

MacKinlay, A. C. (1997). Event studies in economics and finance. Journal of Economic Literature, 35(1), 13-39. 
McWilliams, A., \& Siegel, D. (1997). Event studies in management research: Theoretical and empirical issues. Academy of Management Journal, 40(3), $626-657$.

Mnasri, A., \& Nechi, S. (2016). Impact of terrorist attacks on stock market volatility in emerging markets. Emerging Markets Review, 28, 184-202.

Nelson, D. B. (1991). Conditional heteroskedasticity in asset returns: A new approach. Econometrica: Journal of the Econometric Society, 59(2), 347370.

Palm, F. and Vlaar, P. (1997). Simple diagnostics procedures for modelling financial time series. Allgemeines Statistisches Archiv, 81, 85-101.

Raza, S. A., \& Jawaid, S. T. (2013). Terrorism and tourism: A conjunction and ramification in Pakistan. Economic Modelling, 33, 65-70.

Ryan, C. (1993). Crime, violence, terrorism and tourism: an accidental or intrinsic relationship?. Tourism Management, 14(3), 173-183.

Shahzad, S. J. H., Shahbaz, M., Ferrer, R., \& Kumar, R. R. (2017). Tourism-led growth hypothesis in the top ten tourist destinations: New evidence using the quantile-on-quantile approach. Tourism Management, 60, 223-232.

Shiller, R. J., Fischer, S., \& Friedman, B. M. (1984). Stock prices and social dynamics. Brookings Papers on Economic Activity, 1984(2), 457-510. 
Sönmez, S. F., Apostolopoulos, Y., \& Tarlow, P. (1999). Tourism in crisis: Managing the effects of terrorism. Journal of Travel Research, 38(1), 13-18.

Tang, C. F., \& Abosedra, S. (2014). Small sample evidence on the tourism-led growth hypothesis in Lebanon. Current Issues in Tourism, 17(3), 234-246.

Tang, C. F., \& Tan, E. C. (2015). Does tourism effectively stimulate Malaysia's economic growth?. Tourism management, 46, 158-163.

Tuna, G. (2011). The effectiveness of Central Bank intervention: Evidence from Turkey. Applied Economics, 43(14), 1801-1815.

World Bank. (2019, March 18). Retrieved from https://data.worldbank.org/

World Tourism Organization. (2018, April 13). Retrieved from https://www.eunwto.org/doi/pdf/10.18111/9789284419876

Zopiatis, A., Savva, C. S., Lambertides, N., \& McAleer, M. (2018). Tourism stocks in times of crisis: an econometric investigation of unexpected nonmacroeconomic factors. Journal of Travel Research, https://doi.org/10.1177/0047287517753998 


\section{APPENDIX}




\title{
Appendix A: First Page the Publication of this Thesis in the Journal of Current Issues in Tourism
}

CURRENT ISSUES IN TOURISM

Routledge

https//doiorg/10.1080/13683500.2019.1592124

Taylor \& Francis Grou

Th) Check for updates

The vulnerability of tourism firms' stocks to the terrorist incidents

Dlawar Mahdi Hadi, Salih Katircioglu (C) and Cahit Adaoglu (C)

Department of Banking and Finance, Eastern Mediterranean University, Famagusta, Turkey

\begin{abstract}
This study investigated the effects of terrorist attacks on the stock performance of tourism, travel, and leisure industries. The major tourist countries have been selected for this purpose. The novelty of this research is that not only it focuses on the relationship between terrorism and tourism stock performance and volatility but also uses an event study to examine this relationship. The results of this study revealed the significant effects of terrorist attacks on tourism firms' performance and stock volatility in France, Spain, Thailand, Turkey, the United Kingdom, and the United States, while no significant effects were obtained for China and Germany. The overall panel event study analysis as well as the event study for individual countries illustrated the considerable adverse effects of terrorist attacks on firms' performance in tourism, travel, and leisure industries.
\end{abstract}

\section{ARTICLE HISTORY}

Received 12 September 2018 Accepted 4 March 2019

\section{KEYwORDS}

Tourism; travel; leisure;

terrorism; stock performance

\section{Introduction}

The tourism sector is interrelated to the overall economic growth through various channels. Katircioglu (2009a; 2009b) argues that intemational tourism generates tax revenues that can help gov ernments overcome their budget deficits; it also generates export revenues that can offset the current account deficits and the negative balance of payment. The tourism sector creates employ ment, induces investment in human capital and technoloqy, and stimulates the efficiency of local 